\title{
"Man Is Opposed to Fair Play": An Empirical Analysis of How the Fifth Circuit Has Failed to Take Seriously Atkins v. Virginia
}

Michael L. Perlin

Talia Roitberg Harmon

Sarah Wetzel

Follow this and additional works at: https://digitalcommons.nyls.edu/fac_articles_chapters

Part of the Criminal Procedure Commons, Disability Law Commons, Law and Psychology Commons, Legal Ethics and Professional Responsibility Commons, and the Legal Profession Commons 


\title{
"MAN IS OPPOSED TO FAIR PLAY": AN EMPIRICAL ANALYSIS OF HoW THE FIFTH GIRCUIT HAS FAILED TO TAKE SERIOUSLY ATKINS V. VIRGINIA
}

\author{
MICHAEL L. PERLIN, ESQ. ,† TALIA ROITBERG \\ HARMON, PHD. $\uparrow+$ SARAH WETZEL, B.S; B.A. $\uparrow+\uparrow$
}

\section{INTRODUCTION}

$\coprod$ n 2002, in Atkins v. Virginia, ${ }^{1}$ the United States Supreme Court held that subjecting persons with intellectual disabilities to the death penalty violates the Eighth Amendment. ${ }^{2}$ Since 2002, the Court has returned to this question multiple times, clarifying that

The authors wish to thank Richard Burr, Robert Owen, Jessica Graf, Jeremy Schepers, Scott Smith, David Dow, Cathy Smith, Paula Caplan, and John "Bud" Ritenour for their invaluable and helpful information. A portion of this article was presented via Zoom seminar by Michael L. Perlin to the Georgia Association of Criminal Defense Lawyers, May 1, 2020.

$\dagger$ Professor Emeritus of Law; Founding Director, International Mental Disability Law Reform Project; Co-founder, Mental Disability Law and Policy Associates; New York Law School, 185 West Broadway, New York, NY 10013; Adjunct Professor of Law, Emory University School of Law; Instructor, Loyola University New Orleans, Department of Criminology and Justice; michael.perlin@nyls.edu; mlperlin@mdlpa.net

It Niagara University, Chair and Professor, Department of Criminal Justice and Criminology; Timon Hall Room 12, Niagara University, NY 14091; (716) 286-8093 (o), (716) 286-8079 (fax); tharmon@niagara.edu

$\uparrow \dagger \uparrow$ Niagara University, Niagara University, NY, 14109, swetzel@mail.niagara.edu

1. 536 U.S. 304, 305 (2002).

2. At the time of the Atkins case, the phrase "mental retardation" was used. Id. at 306. Twelve years later, in the case of Hall v. Florida, the Court chose to use the phrase "intellectual disability" rather than "mental retardation" in all future cases to conform with changes in the U.S. Code and in the most recent version of the American Psychiatric Association's Diagnostic and Statistical Manual of Mental Disorders (DSM-5). 134 S. Ct. 1986, 1990 (2014). "Construing and applying the Eighth Amendment in the light of our 'evolving standards of decency,' we therefore conclude that such punishment is excessive and that the Constitution 'places a substantive restriction on the State's power to take the life' of a mentally retarded offender." Atkins, 536 U.S. at 321. This decision came only sixteen years after the Court rejected similar arguments in Penry v. Lynaugh. 492 U.S. 302 (1989). For a spellbinding account of how advocates and advocacy groups persuaded state legislatures to outlaw the death penalty in such cases (one of the major reasons the Supreme Court did an about face after Penry), see James W. Ellis, Disability Advocacy and the Death Penalty: The Road from Penry to Atkins, 33 N.M. L. REV. 173 (2003). 
inquiries into defendants' intellectual disabilities for purposes of determining whether they are potentially subject to the death penalty cannot be limited to a bare numerical "reading" of an intelligence quotient ("IQ") score, ${ }^{3}$ and that state rules based on superseded medical standards unacceptably risk executing persons with intellectual disabilities in violation of the Eighth Amendment. ${ }^{4}$

Atkins and its progeny spawned a cottage industry of commentary on multiple related issues, including the following:

$>$ the ability of counsel and judges to understand the meaning of intellectual disabilities; ${ }^{5}$

$>$ the importance of cultural competency in the process of litigating on behalf of capital defendants with intellectual disabilities; ${ }^{6}$

$>$ the ways that failure to develop evidence of intellectual disability are treated in effectiveness-of-counsel cases; ${ }^{7}$

3. Hall, 134 S. Ct. at 1990; see also Brumfield v. Cain, 135 S. Ct. 2269, 2281 (2015) (holding that a state post-conviction court's determination that prisoner's IQ score of 75 demonstrated that he could not possess subaverage intelligence reflected an unreasonable determination of the facts).

4. Moore v. Texas, 137 S. Ct. 1039, 1044 (2017) (Moore I). Two years later, the Supreme Court returned to Moore's case once again, restating its decision, and criticizing the Texas Court of Criminal Appeals (that had reinstated the death penalty in Moore's case in the interim) for relying on "lay stereotypes of the intellectually disabled." Moore v. Texas, 139 S. Ct. 666, 672 (2019) (Moore II). Those stereotypes emerged from the Texas Court's decision in Ex parte Briseno, which included seven evidentiary factors that it had articulated without any citation "to any authority, medical or judicial." Moore I, 137 S. Ct. at 1046 (citing 135 S.W.3d 1, 8-9 (Tex. Crim. App. 2004)). These factors were largely based on the depiction of a character in John Steinbeck's novel, Of Mice and Men. See Adam Liptak, Supreme Court to Consider Legal Standard Drawn from 'Of Mice and Men', N.Y. Times (Aug. 23, 2016), https://www.nytimes.com/2016/08/23/us/politics/supreme-court-to-consider-legalstandard-drawn-from-of-mice-and-men.html. We discuss the implications of the Briseno factors extensively. See infra note 100.

5. James W. Ellis, Disability Advocacy and Atkins, 57 DePAul L. Rev. 653, 656-64 (2008); see Andrea D. Lyon, But He Doesn't Look Retarded: Capital Jury Selection for the Mentally Retarded Client Not Excluded After Atkins v. Virginia, 57 DEPAul L. Rev. 701 (2008) (discussing judicial comprehension); Caroline Everington, Challenges of Conveying Intellectual Disabilities to Judge and Jury, 23 WM. \& MARY BILL RTS. J. 467 (2014).

6. Jeffrey Omar Usman, Capital Punishment, Cultural Competency, and Litigating Intellectual Disability, 42 U. MEM. L. Rev. 855, 885-904 (2012); see Michael L. Perlin \& Valerie R. McClain, "Where Souls Are Forgotten": Cultural Competencies, Forensic Evaluations and International Human Rights, 15 PSYGH., PUb. POL'Y, \& L. 257 (2009) (discussing why expert witnesses also need this cultural competency).

7. Rebecca Klaren \& Irene Merker Rosenberg, Splitting Hairs in Ineffective Assistance of Counsel Cases: An Essay on How Ineffective Assistance of Counsel Doctrine Undermines the Prohibition Against Executing the Mentally Retarded, 31 AM. J. CRIM. L. 339, 348-66 (2004); see Strickland v. Washington, 466 U.S. 668 (1984); Michael L. Perlin, Talia Roitberg Harmon \& Sarah 
the underlying sanism of jurors in assessing intellectual disabilities; ${ }^{8}$

$>$ the pretextuality of so many judges in assessing such cases; ${ }^{9}$

$>$ the capacity of jurors to empathize with persons with intellectual disabilities; ${ }^{10}$

$>$ the role of experts in explaining:

$\circ$ the meanings of IQs, ${ }^{11}$ functional abilities, capacity for moral development, etc., of persons with intellectual disability; ${ }^{12}$

Chatt, "A World of Steel-Eyed Death": An Empirical Evaluation of the Failure of the Strickland Standard to Ensure Adequate Counsel to Defendants with Mental Disabilities Facing the Death Penalty, 53 U. MICH. J.L. REFORM 261, 296-97 (2020) (discussing how the Fifth Circuit has dealt with effectiveness of counsel claims in the context of Strickland).

8. Sanism is "an irrational prejudice of the same quality and character of other irrational prejudices that cause (and are reflected in) prevailing social attitudes of racism, sexism, homophobia and ethnic bigotry." See Michael L. Perlin, The Sanist Lives of Jurors in Death Penalty Cases: The Puzzling Role of Mitigating Mental Disability Evidence, 8 NOTRE DAME J. L., EThics \& PUb. POL'y 239, 257 (1994) [hereinafter Perlin, Sanist Lives]. For further discussion on sanism in the context of persons with intellectual disabilities, see Keri K. Gould, And Equal Participation for All ... The Americans With Disabilities Act in the Courtroom, 8 J.L. \& HEALTH 123, 140-41 (1994). For further discussion on sanism and the death penalty in general, see John W. Parry, The Death Penally and Persons with Mental Disabilities: A Lethal Dose of Stigma, Sanism, Fear of Violence, and Faulty Predictions of Dangerousness, 29 MENTAL \&. Physical Disability L. ReP. 667 (2005); see also Lyon, supra note 5.

9. See Michael L. Perlin, "Merchants and Thieves, Hungry for Power": Prosecutorial Misconduct and Passive Judicial Complicity in Death Penalty Trials of Defendants with Mental Disabili ties, 73 WASH. \& LEE L. REV. 1501, 1506 n.19 (2016) (discussing the "consistently pretextual positions of four current Supreme Court judges in all matters dealing with the overlap between mental disability and criminal behavior, culminating in Justice Alito's bizarre dissent in Hall [v. Florida].") [hereinafter Perlin, Merchants and Thieves]; see infra notes 95-96 (discussing Justice Alito's dissent further). See also Michael L. Perlin, "Half-Wracked Prejudice Leaped Forth": Sanism, Pretextuality, and Why and How Mental Disability Law Developed as It Did, $10 \mathrm{~J}$. CONTEMP. LEGAL Issues 3 (1999) (discussing pretextuality further). We define "pretextuality" as "the ways in which courts accept testimonial dishonesty-especially by expert witnesses—and engage similarly in dishonest (and frequently meretricious) decision-making." Perlin, Harmon \& Chatt, supra note 7, at 280 n.117.

10. See Denise Paquette Boots, Kathleen M. Heide \& John K. Cochran, Death Penalty Support for Special Offender Populations of Legally Convicted Murderers: Juveniles, the Mentally Retarded, and the Mentally Incompetent, 22 BEHAV. SGI. \& L. 223 (2004).

11. Daniel B. Kessler, Atkins v. Virginia: Suggestions for the Accurate Diagnosis of Mental Retardation, 43 JuRIMETRICS J. 415, 424-26 (2003).

12. See John M. Fabian, Death Penalty Mitigation and the Role of the Forensic Psychologist, 27 L. \& Psych. ReV. 73 (2003). 
○ the potential for misuse of "ethnic adjustments" to make certain persons with lower IQs eligible for the death penalty; ${ }^{13}$ and

○ the extent to which judges can adequately understand such expert testimony; ${ }^{14}$ the willingness of trial judges to enforce Atkins; ${ }^{15}$ and

$>$ the extent to which the fear-of-faking concern is valid, which Justice Scalia focused on in his Atkins dissent. ${ }^{16}$

Atkins' victory-and the victories of other defendants with intellectual disabilities in subsequent Supreme Court cases ${ }^{17}$-may be illusory unless we look carefully at these issues and a constellation of other legal, social, and behavioral issues that poisoned this area of the law for decades. Atkins gives us a blueprint, but the question remains as to whether the case will, in the long run, be more than a "paper victory." ${ }^{18}$ Until these issues are carefully considered, the true legacy of Atkins and its progeny will not be clear, and it will similarly be unclear if the case's "revolutionary potential" will be fulfilled. ${ }^{19}$

13. Robert M. Sanger, IQ Intelligence Tests, "Ethnic Adjustments," and Atkins, 65 AM. U. L. REV. 87, 108-16 (2015); David L. Shapiro et al., Ethnic Adjustment Abuses in Forensic Assessment of Intellectual Abilities, 4 PRAC. InNovations 265 (2019); Michael L. Perlin, "Your Cormut Ways Had Finally Made You Blind": Prosecutorial Misconduct and the Use of "Ethnic Adjustments" in Death Penalty Cases of Defendants with Intellectual Disabilities, 65 AM. U. L. REV. 1437 (2016) [hereinafter Perlin, Corrupt Ways].

14. James W. Ellis, Caroline Everington \& Ann M. Delpha, Evaluating Intellectual Disability: Clinical Assessments in Atkins Cases, 46 HofstRA L. REV. 1305, 1424-26 (2018); see also Everington, supra note 5.

15. Joseph A. Migliozzi, Jr. \& Ashley Hughes, Atkins Test for Excluding Intellectually Disabled Persons from Execution Withstands Barrage of Challenges by State Courts, 30 REgENT U. L. REV. 135, 142-48 (2017); see Perlin, Harmon \& Chatt, supra note 7 (discussing trial judges' failure/refusal to implement other Supreme Court decisions in cases involving defendants with mental disabilities facing the death penalty).

16. Bridget M. Doane \& Karen L. Salekin, Susceptibility of Current Adaptive Behavior Measures to Feigned Deficits, 33 L. \& HuM. BeHAV. 329, 329-31 (2009). See generally MichaEL L. Perlin \& Heather Ellis Cucolo, Mental Disability LaW: Civil and Criminal, $\$ 17-$ 4.2.2 (3d ed. 2016) (2020 update).

17. See Hall v. Florida, 134 S. Ct. 1986 (2014); Brumfield v. Cain, 135 S. Ct. 2269 (2015); Moore v. Texas, 137 S. Ct. at 1044 (2017) (Moore I); Moore v. Texas, 139 S. Ct. 666 (2019) (Moore II).

18. Michael L. Perlin, "Life Is in Mirrors, Death Disappears": Giving Life to Atkins, 33 N.M. L. REV. 315, 315 (2003) [hereinafter Perlin, Life Is in Mirrors].

19. See Scott E. Sundby, The True Legacy of Atkins and Roper: The Unreliability Principle, Mentally Ill Defendants, and the Death Penalty's Unraveling, 23 WM. \& MARY BILL RTS. J. 487, 487 (2014). 
In a recent article, two co-authors (Michael L. Perlin and Talia Roitberg Harmon) and a colleague considered all of the death penalty cases involving defendants with mental disabilities decided by the Fifth Circuit in the thirty-six years since Strickland, in an effort to assess its empirical impact on this population. ${ }^{20}$ We found that the Fifth Circuit's corpus in this area of the law was "bizarre and frightening," ${ }^{21}$ noting that, "in virtually all cases, Strickland errorsoften, egregious errors - were ignored, and in over a third of the cases in which they were acknowledged, defense counsel had confessed error," 22 concluding that this cohort of cases was "an embarrassment to our system of criminal law and procedure." 23

Here, we shift focus but stay with a related database: to what extent has the Fifth Circuit given meaningful life to Atkins and its progeny? ${ }^{24}$ Besides considering the effectiveness of counsel, we will focus primarily on decisions revolving around the specter of malingering, ${ }^{25}$ the so-called "Flynn Effect," ${ }^{26}$ the type of IQ test given, ${ }^{27}$ what are now known as ethnic adjustment cases, ${ }^{28}$ and to a lesser extent, issues involving adequacy of counsel, ${ }^{29}$ and the alleged lack of remorse. ${ }^{30}$ As we will discuss, most of the few "victories" at this

20. See Perlin, Harmon \& Chatt, supra note 7; Strickland v. Washington, 466 U.S. 668 (1984) (test for adequacy of counsel in criminal cases), discussed infra text accompanying notes 263-65.

21. Perlin, Harmon \& Chatt, supra note 7 , at 308.

22. Id.

23. Id. at 309 .

24. We have limited our analysis to cases from the Fifth Circuit (cases originating from Texas, Mississippi, and Louisiana) for multiple reasons, such as: (1) states in this Circuit, especially Texas, frequently use the death penalty; (2) a significant number of the most important death penalty cases that have reached the Supreme Court have come from this circuit; (3) this circuit has shown a stunning disregard of mitigating evidence in all types of death cases; and (4) in a similar area, competency to be executed, the Fifth Circuit has demonstrated an "equally-stunning disregard for constitutional law." Id. at 285.

25. See generally Ellis, Everington \& Delpha, supra note 14.

26. See, e.g., Geraldine W. Young, A More Intelligent and Just Atkins: Adjusting for the Flynn Effect in Capital Determinations of Mental Retardation or Intellectual Disability, 65 VAND. L. REV. 615 (2012).

27. See, e.g., James Flynn, Tethering the Elephant, 12 Psychol., Pub. PoL'Y, \& L. 170 (2006).

28. See, e.g., Shapiro et al., supra note 13, at 1-2.

29. See generally Perlin, Harmon \& Chatt, supra note 7.

30. See, e.g., William Geimer \& Jonathan Amsterdam, Why Jurors Vote Life or Death: Operative Factors in Ten Florida Death Penalty Cases, 15 AM. J. CRIM. L. 1, 51-52 (1988); Perlin, Merchants and Thieves, supra note 9, at 1530-31 (discussing further how the lack of remorse can affect the jury's decision). 
level were pyrrhic: cases were remanded or vacated, but the initial determination was eventually reinstated. ${ }^{31}$

In the universe of seventy Atkins cases (that is, cases in the Fifth Circuit in which colorable Atkins-based arguments had been raised by defendants on habeas corpus applications), only nine cases (12\%) had actual and meaningful relief granted to defendants (their sentences were commuted to life in prison, with one of those defendants having a parole hearing scheduled). ${ }^{32}$ In forty of the seventy cases $(57 \%)$, the Circuit affirmed, denying applications for writs of habeas corpus in most instances. ${ }^{33}$ Eight cases $(11 \%)$ are still pending, meaning there was a remand from the Fifth Circuit or a grant of a certificate of appealability, and further proceedings are currently taking place or being scheduled. ${ }^{34}$ In thirteen cases $(18.5 \%)$, although preliminary relief had been granted, defendants were ultimately unsuccessful. As of the writing of this article, ten defendants have been executed, one execution has been stayed because of COVID-19-related reasons, one defendant has died in prison, and one remains on death row. ${ }^{35}$ In short, if every one of

31. See infra note 137 (listing cases where the Atkins claims were partially successful but ultimately failed).

32. See infra note 130 . In two of these nine cases in which preliminary relief was granted, the defendant died in prison before there was a final disposition of the case (which is why we cannot characterize that relief as "meaningful"). Thus, there was bona fide relief in just seven. See infra Appendix B, listing cases.

33. See infra note 134 (citing several of the forty cases where the Circuit court affirmed a decision against the defendant).

34. In all cases in which defendants had bona fide success, the authors have written to counsel listed on Westlaw as having represented the defendant in the last reported case, seeking further developments. In some instances, counsel did respond; in others, they did not. See infra Appendix C.

35. See infra note 183; see also Michael Graczyk, Michael Wayne Hall Executed For his Role in Torture-Slaying, CBSN DALLAS - FORT WORTH (Feb 15, 2011, 1:55 PM), https:/ / dfw.cbslocal.com/2011/02/15/michael-wayne-hall-executed-for-his-role-in-tourture-slaying; Texas Executes Yokamon Hearn with Pentobarbitol, BBC News (July 19, 2012), https://www.bbc.com/news/world-us-canada-18897310; Ed Pilkington Texas Executes Intellectually Disabled Killer Robert Ladd, THE GuARDian (Jan 29, 2015, 9:12 PM), https://www.theguardian.com/us-news/2015/jan/30/texas-executes-robert-ladd-intellectually-disabled-prisoner; Crimesider, Ricky Lynn Lewis, Convicted Texas Murderer, to be executed Tuesday; CBS News (Apr. 9, 2013, 11:37 AM), https://www.cbsnews.com/ news/rickey-lynnlewis-convicted-texas-murderer-to-be-executed-tuesday; Maldondao v. Thaler, 625 F. 3d 229 (5th Cir. 2010), cert. denied, 565 U.S. 829 (2011) (denying Maldondao a stay of execution); Texas Death Row Inmate in 25-Year House Case Loses Appeal, NBC 5 DALLAS-FORT WORTH (Apr. 7, 2015), https://www.nbcdfw.com/news/local/texas-death-row-inmate-in-25-year-houston-case-loses-appeal/1998968 (reporting that John Reyes Matamoros lost his appeal); John Rudolf, Milton Mathis, Convicted Killer, Executed in Texas Despite Evidence of Retardation, HufFPost (June 21, 2011, 10:10 PM), https://www.huffpost.com/entry/milton-mathis- 
the defendants in pending cases is successful (an outcome that, based on the Fifth Circuit's track record, is certainly not likely), Atkins' claims will have been successful in just $24 \%$ of all cases. ${ }^{36}$

Our findings also reveal important patterns as to why certain defendants were successful, ${ }^{37}$ and why the majority was unsuccessful. Defendants who (1) rebutted allegations of "malingering," 38 (2) raised the Flynn Effect, ${ }^{39}$ and (3) relied upon the Wechsler Adult Intelligence Scale ("WAIS") IQ test, ${ }^{40}$ were more likely to receive preliminary relief. On the other hand, the findings revealed that defendants were less likely to be successful when they used the Wechsler Adult Intelligence Scale for Children ("WISC") IQ test or when there was no rebuttal for malingering claims. ${ }^{41}$ It also appeared that partial cases turned into failures when there was no rebuttal provided for malingering claims, when prima facie cases were

executed-killer_n_881885; Michael Graczyk, Man Convicted of Robbery Death Executed in Texas, SAN Diego UnION-Trib. (Mar. 4, 2009, 5:15 PM) https://www.sandiegouniontribune.com/sdut-texas-execution-030409-2009mar04-story.html; Texas Executes Michael Rosales, KCBD News (Apr. 15, 2009, 10:35 PM), https://www.kcbd.com/story/10191455/texas-executes-michael-rosales /\#: :text=HUNTSVILLE $\% 2 \mathrm{C} \% 20 \mathrm{TX} \% 20(\mathrm{KCBD}) \% 20 \% 2 \mathrm{D}$, inside \%20her\%20North\%200verton\%20home; Paul Stone, Simpson Executed, PALESTINE HERALD-PRESS (Nov. 18, 2009), https://www.palestineherald.com/news/local_news/simpson-executed/article_faa00786-d0f3-51a7-a770-a0dd3b08b6e3.html; John Rudolf, Marvin Wilson Execution: Texas Puts Man With 61 IQ to Death, HufFPost (Aug. 7, 2012, 8:53 PM), https://www.huffpost.com/entry/marvin-wilson-execution-texas_n_1753968; Chris McGreal, Texas Executes Man at Centre of Mental Disability Row, THE GuARDIAN, (Dec. 4 2009, 10:28 AM), https://www.theguardian.com/world/2009/dec/04/texas-execution-mentaldisability-iq.

36. This statistic $(9 / 70)$ includes the two cases in which clients died before the relief could be implemented. For an earlier (national) empirical evaluation of Atkins claims, see John Blume et al., An Empirical Look at Atkins v. Virginia and its Application in Capital Cases, 76 TENN. L. REV. 625, 627-28 (2009) (concluding that "Atkins has not opened floodgates of non-meritorious litigation.") [hereinafter Blume et al., An Empirical Look].

37. Here the word "successful" is being used in a broader context. It means that, at the least, there was some preliminary relief granted under Atkins, mostly cases in which certificates of appealability were granted. See infra Section III.C.

38. See, e.g., Moore v. Quarterman, 342 F. App'x 65, 66, 71 (5th Cir. 2015); Brumfield v. Cain, 808 F.3d 1041, 1060 (5th Cir. 2015); Wiley v. Epps, 625 F.3d 199, 221-22 (5th Cir. 2010).

39. See, e.g., Moore, 342 F. App'x at 66, 81-82; Wiley, 625 F.3d at 202-03, 214 (stating that "the Flynn effect is generally accepted in the scientific community.").

40. See, e.g., Moore, 342 F. App'x at 66, 68; (stating that Atkins names the WAIS test as "the standard instrument for measuring intellectual functions"); Brumfield, 808 F.3d at 1043, 1047-48; Wiley, 625 F.3d at 202-03.

41. See infra text accompanying note 162 (noting the only case where the WISC test was potentially successful in granting preliminary relief). 
made and evidentiary hearings ordered, or when Dr. George Denkowski's discredited testimony was before the court. ${ }^{42}$

First, we discuss the Atkins case and the significance of the post-Atkins cases of Hall, Moore I, and Moore II, focusing on that trilogy's modification of Atkins and its reinforcement of some of Atkins' most salient points. ${ }^{43}$ Following this, we will examine the universe of Fifth Circuit cases applying (often, misapplying) Atkins, explaining our methodology and revealing our findings. ${ }^{44}$

We then consider this entire area of law and policy through the lens and filter of therapeutic jurisprudence, ${ }^{45}$ and subsequently apply that doctrine's principles to the database of the cases in question. ${ }^{46}$ We conclude by offering some modest suggestions focusing on how we can finally, some seventeen years after one of us used this phrase in a title of another law review article about Atkins, "giv[e] life" to this case. ${ }^{47}$

Our title comes, in part, from Bob Dylan's song License to Kill, ${ }^{48}$ which is about corruption and "the havoc man wreaks upon himself." "Through its interpretation of Atkins cases, the Fifth Circuit has "wreak[ed] havoc" on both the litigants before it and the legal system itself. In an earlier article, one of the co-authors (Michael L. Perlin) discussed the malevolent use of "ethnic adjustments" to improperly-and corruptly-make certain defendants with intellectual disabilities inappropriately eligible for the death

42. See infra text accompanying notes 226-39; see also infra notes $206,210$.

43. See infra Part II.

44. See infra Part III. It is important to note that, in nearly a majority of those cases in which there was some initial relief offered by the Fifth Circuit, it appeared that the state argued that the defendant was malingering intellectual disability (something that virtually every expert in the world tells us is impossible to accurately do). See infra notes 153-55 and accompanying text.

45. See infra Section IV.A.

46. See Section IV.B.

47. See Perlin, Life Is in Mirrors, supra note 18; see also, infra Part V.

48. Bob Dylan, License to Kill, SoNY Music ENT. (2018), https://www.bobdylan.com/songs/license-kill. One of the co-authors has relied on another lyric from this song once previously. See Michael L. Perlin, "His Brain Has Been Mismanaged with Great Skill: How Will Jurors Respond to Neuroimaging Testimony in Insanity Defense Cases?, 42 AKRoN L. REV. 885, 888 (2009) [hereinafter Perlin, Neuroimaging Testimony].

49. Oliver Trager, Keys to the Rain: The Definitive Bob Dylan Encyclopedia $376-77(2004)$. 
penalty.$^{50}$ This entire database of cases, and the decision-making of the Fifth Circuit, is a reflection of such corruption.

\section{THE CASE LAW}

The significance of Atkins is crystal-clear from Justice Stevens' opening paragraph:

Those mentally retarded persons who meet the law's requirements for criminal responsibility should be tried and punished when they commit crimes. Because of their disabilities in areas of reasoning, judgment, and control of their impulses, however, they do not act with the level of moral culpability that characterizes the most serious adult criminal conduct. Moreover, their impairments can jeopardize the reliability and fairness of capital proceedings against mentally retarded defendants. ${ }^{51}$

Presumably for these reasons, in the thirteen years since the Supreme Court decided Penry v. Lynaugh, ${ }^{52}$ the American public, legislators, scholars, and judges have deliberated the question whether the death penalty should ever be imposed on an intellectually disabled criminal. The consensus reflected in those deliberations informs our answer to the question presented by this case: whether such executions are "cruel and unusual punishments" prohibited by the Eighth Amendment of the United States Constitution. ${ }^{53}$

In the penalty phase of Atkins' capital murder trial, the defense called a forensic psychologist who had testified that Atkins was, per the language used at that time, "mildly mentally

50. See, e.g., Perlin, Corrupt Ways, supra note 13, at 1440 (discussing how the use of "ethnic adjustments ... endors [es] and sanction [s] the use of this 'corrupt science").

51. Atkins, 536 U.S. at 306.

52. See Penry v. Lynaugh, 492 U.S. 302, 333-34 (dismissing Penry's argument that there was an "emerging national consensus" against execution of persons with retardation, noting that only one state had legislatively banned such executions and rejected Penry's evidence on this point of public opinion surveys as an "insufficient basis" upon which to ground an Eighth Amendment prohibition); see Perlin, Corrupt Ways, supra note 13, at 1448 n.58.

53. Atkins, 536 U.S. at 306-07. 
retarded." ${ }^{44}$ After Atkins' death sentence was set aside (for reasons unrelated to the subject of this article), the same witness testified at the rehearing. ${ }^{55}$ The state's rebuttal witness testified, however, that the defendant was not intellectually disabled, that he was "of average intelligence, at least[,]" and that his appropriate diagnosis was antisocial personality disorder. ${ }^{56}$ The jury resentenced Atkins to death, and the Virginia Supreme Court affirmed, over a dissent that characterized the state's expert's testimony as "incredulous as a matter of law," and argued that the imposition of the death sentence on one "with the mental age of a child between the ages of 9 and 12 [was] excessive." ${ }^{57}$

The Supreme Court underscored that the "clearest and most reliable objective evidence of contemporary values is the legislation enacted by the country's legislatures." 58 It stressed, on this point, the significant changes in the thirteen years since its Penry decision, during which time, at least sixteen states (and the federal government) had enacted laws banning such executions. ${ }^{59}$ This about-face provided "powerful evidence that today our society views mentally retarded offenders as categorically less culpable than the average criminal," ${ }^{60}$ a finding leading it to conclude that "it is fair to say that a national consensus has developed against it."61

It is especially important that the Court, given its subsequent decisions in Hall and the two opinions in Moore, added that a determination as to whether Atkins applies involves a finding more

54. Id. at 308. Atkins's IQ was 59. Id. at 309. See generally Mark E. Olive, The Daryl Atkins Story, 23 WM. \& MARY BILL RTS. J. 363, 368-74 (2014) (discussing Atkins and the rule of the important "players").

55. Atkins, 536 U.S. at 338.

56. Id. at 309 (testimony of Dr. Stanton Samenow). In other contexts, Dr. Samenow has publicly stated that "criminals are a 'different breed of person,' who seek to manipulate the system for their own ends." See Ramdass v. Angelone, 187 F.3d 396, 410-11 n.1 (4th Cir. 1999) (Murnaghan, J., concurring) (citing, in part, trial transcript); Paul C. Giannelli, Ake v. Oklahoma: The Right to Expert Assistance in a Post-Daubert, Post-DNA World, 89 Cornell L. REV. 1305, 1415 (2004). Dr. Samenow "has abandoned sociologic, psychologic, and mental illness explanations for criminal behavior and holds the view that 'most diagnoses of mental illness [in criminals] resulted from the criminal's fabrications." Id.

57. Atkins v. Commonwealth, 534 S.E.2d 312, 323-24 (Va. 2000).

58. Atkins, 536 U.S at 312 (quoting Penry v. Lynaugh, 492 U.S. 302, 331 (1989)).

59. Id. at 313-15; see also Ellis, supra note 5, at 175-76.

60. Atkins, 536 U.S at 316 .

61. Id. at $315-16$. The court added that this consensus "unquestionably reflects widespread judgment about the relative culpability of mentally retarded offenders, and the relationship between mental retardation and the penological purposes served by the death penalty." Id. at 317. 
nuanced than simply a recitation of IQ scores: intellectual disability involved "not only subaverage intellectual functioning, but also significant limitations in adaptive skills such as communication, selfcare, and self-direction that became manifest before age eighteen." 62

The Court concluded that this cohort of defendants should be "categorically excluded from execution." 63 The retribution and deterrence rationales that underlay the decision sanctioning the death penalty in Gregg v. Georgia ${ }^{64}$ did not apply to intellectually disabled offenders; ${ }^{65}$ such application would be nothing more than "the purposeless and needless imposition of pain and suffering," and hence an unconstitutional punishment. ${ }^{66}$ The Court also rejected both retribution and deterrence rationales for allowing such executions. ${ }^{67}$

The Court concluded that there was an "enhanced" risk of an improperly-imposed death penalty in cases involving defendants with an intellectual disability because of the possibility of false confessions, as well as "the lesser ability of mentally retarded defendants to make a persuasive showing of mitigation in the face of prosecutorial evidence of one or more aggravating factors." ${ }^{6}$

62. Id. at 318. Writing after the Court's subsequent decision in Moore $v$. Texas (Moore II), requiring a far broader picture of the defendant's mental capabilities to be painted than was typically done in the pre-Atkins years, Professors Alexander $\mathrm{H}$. Updegrove and Michael S. Vaughn stressed: "Although it is difficult to find these sources, it is preferable to conduct interviews with people who have had long-term interactions with the defendant during different developmental stages, including family members, teachers, neighbors, acquaintances, employers, and religious counselors." Evaluating Intellectual Disability after the Moore v. Texas Redux, 47 J. AM. ACAD. Psychiatry \& L. 486, 493 (2019).

63. Atkins, 536 U.S at 318.

64. Gregg v. Georgia, 428 U.S. 153, 183 (1976).

65. Atkins, 536 U.S. at $319-20$.

66. Id. at 318-19 (quoting Enmund v. Florida, 458 U.S. 782, 798 (1982)).

67. On retribution: "if the culpability of the average murderer is insufficient to justify the most extreme sanction available to the State, the lesser culpability of the mentally retarded offender surely does not merit that form of retribution." Id. at 319 . On deterrence: "capital punishment can serve as a deterrent only when murder is the result of premeditation and deliberation," and a "cold calculus" that was at the opposite end of the spectrum from behavior of offenders with an intellectual disability. Atkins, 536 U.S. at 319 (quoting Enmund, 458 U.S. at 799).

68. Id. at 320 . The Court also stressed several additional interrelated issues: the difficulties that persons with an intellectual disability may have in being able to give meaningful assistance to their counsel, their status as "typically poor witnesses," and the ways that their demeanor "may create an unwarranted impression of lack of remorse for their crimes." Id. at 320-21. See generally Judith M. Barger, Avoiding Atkins v. Virginia: How States Are 
The Court expressed concern that "reliance on mental retardation as a mitigating factor can be a two-edged sword that may enhance the likelihood that the aggravating factor of future dangerousness will be found by the jury, ${ }^{69}$ raising the specter that "mentally retarded defendants in the aggregate face a special risk of wrongful execution." 70 This reality led the Court to conclude that such was "excessive" and thus barred by the Constitution. ${ }^{71}$

There were two dissents, by Chief Justice Rehnquist and Justice Scalia. ${ }^{72}$ Importantly, for the purposes of this paper, Justice Scalia expressed his "fear of faking""73:

One need only read the definitions of mental retardation adopted by the American Association of Mental Retardation and the American Psychiatric Association to realize that the symptoms of this condition can readily be feigned. And ... the capital defendant who feigns mental retardation risks nothing at all. ${ }^{74}$

Circumventing Both the Letter and the Spirit of the Court's Mandate, 13 BERKELEY J. CRIM. L. 215, 222-26 (2008) (discussing this aspect of Atkins).

69. Atkins, 536 U.S. at 321 (citing Penry v. Lynaugh, 492 U.S. 302, 323-25 (1989)).

70. Id. at 321. On wrongful convictions in general, see Talia Harmon et al., Post-Furman Death Row Exonerations and Publicity in the News, 52 CRIM. L. Bull., Art. 3 (2016).

71. Atkins, $\mathbf{5 3 6}$ U.S. at 321.

72. The Chief Justice (joined by Justice Thomas and Justice Scalia) criticized that part of the majority's methodology that had relied upon public opinion polls, the views of professional and religious organizations, and the status of the death penalty in other nations as part of the basis for its decision. Id. at 328 (Rehnquist, C.J., dissenting). Justice Scalia also dissented (joined by Chief Justice Rehnquist and Justice Thomas) flatly rejecting the notion that there was a "consensus" against the execution of persons with mild mental retardation. Id. at 344 (Scalia, J., dissenting).

73. Id at 353-54.

74. Id. at 353. See generally Michael L. Perlin, "The Borderline Which Separated You from Me": The Insanity Defense, the Authoritarian Spirit, the Fear of Faking, and the Culture of Punishment, 82 IOWA L. REv. 1375, 1408-16 (1997) [hereinafter Perlin, Borderline]. On how Scalia's opinion is a "pathetic recapitulation of [a] dreary myth," see Perlin, Life Is in Mirrors, supra note 18, at 344 (as discussed in Michael L. Perlin, "Simplify You, Classify You": Stigma, Stereotypes and Cizil Rights in Disability Classification Systems, 25 GA. ST. U. L. REV. 607, 635 n.123 (2009) [hereinafter Perlin, Simplify]). A more-recent exhaustive empirical analysis has found this fear "unfounded." See John H. Blume, Sheri Lynn Johnson \& Katherine E. Ensler, Killing the Oblivious: An Empirical Study of Competency to be Executed Litigation, 82 UMKC L. REV. 335, 354 (2014); John H. Blume et al., A Tale of Two (and Possibly Three) Atkins: Intellectual Disability and Capital Punishment Twelve Years after The Supreme Court's Creation of a Categorical Bar, 23 WM. \& MARY BILl RTS. J. 393, 396-98 (2014) (same) [hereinafter Blume et al., A Tale of Two Atkins]; see also infra notes 145-50. 
"Nothing has changed," he concluded, in the nearly 300 years since Hale wrote his Pleas of the Crown:

[Determination of a person's incapacity] is a matter of great difficulty, partly from the easiness of counterfeiting this disability . . . and partly from the variety of the degrees of this infirmity, whereof some are sufficient, and some are insufficient to excuse persons in capital offenses. ${ }^{75}$

Atkins was first clarified, modified, and expanded upon in Hall v. Florida, ${ }^{76}$ which made clear that inquiries into defendants' intellectual disabilities for the purpose of determining whether they are potentially subject to the death penalty cannot be limited to a bare numerical "reading" of an IQ score. ${ }^{77}$ Under Florida law, if a defendant's IQ was seventy or below, he was deemed to be intellectually disabled; if, however, his IQ measured at seventy-one or above, all further inquiries into intellectual disability ${ }^{78}$ on the question of the application of Atkins - were barred. ${ }^{79}$ Hall declared this rule unconstitutional for creating an "unacceptable risk" that persons with intellectual disabilities would be executed. ${ }^{80}$

In his majority opinion in Hall, Justice Kennedy reiterated a major point of Atkins: ${ }^{81}$ that this population in question faced "a

75. Atkins, 536 U.S. at 354 (quoting 1 Hale, Pleas OF ThE Crown 32-33 (1736)) (Justice Scalia cited no source more recent than this pre-Revolutionary War Treatise).

76. Hall v. Florida, 134 S. Ct. 1986 (2014). See generally James Ellis, Hall v. Florida: The Supreme Court's Guidance in Implementing Atkins, 23 WM. \& MARY BILL RTS. J. 383 (2014); Blume et al., An Empirical Look, supra note 36.

77. Hall, 134 S Ct. at 1995. Prior to the decision in Hall, the Fifth Circuit ordered Atkins to be applied retroactively. See Bell v. Cockrell, 310 F.3d 330 (5th Cir. 2002). On the other hand, that court declined to apply Hall retroactively, while pointing out that Hall dealt with "a formulaic IQ standard that had been used by the state of Florida but never in Texas[.]" Weathers v. Davis, 915 F.3d 1025, 1028 (5th Cir. 2019).

78. On this issue and the implications of changes in the American Psychiatric Association's then-recent version of the Diagnostic and Statistical Manual (DSM-5), see, e.g., Jill V. Feluren, Moving the Focus Away From the IQ Score Towards the Subjective Assessment of Adaptive Functioning: The Effect of The DSM-5 on the Post-Atkins Categorical Exemption of Offenders with Intellectual Disability from the Death Penalty, 38 NovA L. REV. 323 (2014); Kate Janse van Resnburg, The DSM-5 and Its Potential Effects on Atkins v. Virginia, 3 Mental HEALTH L. \& POL'Y 61 (2013); Octavia Gory, Safeguarding the Constitutional Rights of the Intellectually Disabled: Requiring Courts to Apply Criteria That Do Not Deviate from the Current Edition of the DSM, 24 WIDENER L. REV. 155 (2018).

79. Hall, 134 S. Ct. at 1994.

80. Id. at 1990.

81. See Atkins, 536 U.S. at 320-21. 
special risk of wrongful execution" because "they are more likely to give false confessions, are often poor witnesses, and are less able to give meaningful assistance to their counsel." 82 This led to a specific question before the Court: how was intellectual disability to be defined for purposes of executability? ${ }^{83}$

Justice Kennedy turned to the "medical community's opinions" on this issue ${ }^{84}$ noting that that community defined intellectual disability according to three criteria: "significantly subaverage intellectual functioning, deficits in adaptive functioning (the inability to learn basic skills and adjust behavior to changing circumstances), and onset of these deficits during the developmental period." ${ }^{85}$ The first two of these criteria were central, he said, as they had "long been" the defining characteristic of intellectual disability. ${ }^{86}$

State law thus forbade Florida sentencing courts from considering "even substantial and weighty evidence of intellectual disability as measured and made manifest by the defendant's failure or inability to adapt to his social and cultural environment, including medical histories, behavioral records, school tests and reports, and testimony regarding past behavior and family circumstances," ${ }^{87}$ notwithstanding the fact that the medical community accepts all of this evidence as probative of intellectual disability, whether or not an individual's score is over or below seventy IQ points. ${ }^{88}$

Florida law contradicted all professional judgment. "The professionals who design, administer, and interpret IQ tests have agreed, for years now, that IQ test scores should be read not as a single fixed number but as a range." 89 The Court stressed: "An

82. Hall, 134 S. Ct. at 1993 (quoting, in part, Atkins, 536 U.S. at 320-21).

83. In ruling that Hall had no impact on Texas's use of the Briseno factors (later discredited in Moore v. Texas, 139 S. Ct. 666 (2019) (Moore II)), the Fifth Circuit further noted that, "Texas has never adopted the bright-line cutoff at issue in Hall." Mays $v$. Stephens, 757 F.3d 211, 218 (5th Cir. 2014). Although that is true, there is much more in Hall than merely a repudiation of a bright-line standard. See infra notes 88-94 and accompanying text.

84. Hall, 134 S. Ct. at 1993.

85. Id. at 1994 (citing Atkins, 536 U.S. at 308 n.3; Brief for American Psychological Association et al. as Amici Curiae Supporting Petitioner, McCarver v. North Carolina, 533 U.S 975 (2001) (No. 00-8727), 2001 WL 648606 at 12-13 [hereinafter APA Brief]).

86. Hall, 134 S. Ct. at 1994 (quoting APA Brief, supra note 85, at 11).

87. Id.

88. Id. (citing APA Brief, supra note 85, at 15).

89. Id. at 1995; see Courtney Johnson, "Moore" Than Just a Number: Why IQ Cutoffs Are an Unconstitutional Measure for Determining Intelleciual Disability, 91 S. CAL. L. REV. 753, 791

(2018) ("The term 'intellectual disability' does not refer to a single disorder or disease, but 
individual's intellectual functioning cannot be reduced to a single numerical score." ${ }^{90}$ It was thus error to use such a test score "without necessary adjustment." ${ }^{91}$ As the "vast majority" of states had rejected a strict seventy point cutoff, and as the trend to recognize the significance of the standard error of measurement was "consisten [t]," this was, to the Court, "strong evidence of consensus that our society does not regard this strict cutoff as proper or humane." 92

The Court also stressed that neither Florida nor its supporting amici could point to "a single medical professional who supports this cutoff," and that the state's rule went against "unanimous professional consensus." 93 Intellectual disability, Justice Kennedy underscored, "is a condition, not a number." ${ }^{94}$ He concluded:

The death penalty is the gravest sentence our society may impose. Persons facing that most severe sanction must have a fair opportunity to show that the Constitution prohibits their execution. Florida's law contravenes our Nation's commitment to dignity and its duty to teach human decency as the mark of a civilized world. The States are laboratories for experimentation, but those experiments may not deny the basic dignity the Constitution protects. ${ }^{95}$

In his dissent, Justice Alito disagreed, arguing that the positions of professional associations "at best, represent the views of a

rather to a heterogeneous set of disabilities that affect the level of a person's functioning in defined domains." (quoting Coleman v. State, 341 S.W.3d 221, 230 (Tenn. 2011))).

90. Hall, 134 S. Ct. at 1995 (emphasis added). Also, the Court added, "because the test itself may be flawed, or administered in a consistently flawed manner, multiple examinations may result in repeated similar scores, so that even a consistent score is not conclusive evidence of intellectual functioning." Id. at 1995-96.

91. Id. at 1996.

92. Id. at 1998. The Court also considered post-Atkins legislative developments, concluding that "every state legislature to have considered the issue after Atkins-save Virginia's - . . whose law has been interpreted by its courts has taken a position contrary to that of Florida." Id.

93. Id. at 2000 (quoting in part APA Brief, supra note 85, at 15 (emphasis added)).

94. Id. at 2001 .

95. Id. An important commentary on Hall has underscored: "Disproportionate reliance on IQ cutoffs not only fails to capture an individual's adaptive functioning and various sources of test error, but also ignores the necessity of comprehensive neuropsychological testing in assessing a defendant's potential for rehabilitation." Brian $\mathbf{K}$. Cooke, Dominque Delalot \& Tonia L. Werner, Hall v. Florida: Capital Punishment, IQ, and Persons with Intellectual Disabilities, 43 J. AM. ACAD. Psychiatry \& L. 230, 234 (2015). 
small professional elite," ${ }^{96}$ concluding that Florida's standard was "sensible," comporting with the "longstanding belief that IQ tests are the best measure of intellectual functioning." 97

The Court returned to this issue soon after its decision in Hall, holding in Brumfield v. Cain that a state court's postconviction determination that prisoner's IQ score of seventy-five demonstrated that he could not possess subaverage intelligence reflected an unreasonable determination of the facts. ${ }^{98}$ Then, it held in Moore $v$. Texas (Moore I), ${ }^{99}$ that state rules-based on superseded medical standards ${ }^{100}$ — created an unacceptable risk that a person with intellectual disabilities could be executed in violation of the Eighth

96. Hall, $134 \mathrm{~S}$. Ct. at 2005 (emphasis added).

97. Id. at 2007. Justice Alito cited no source to support the adjective "longstanding." $I d$. The Chief Justice, Justice Scalia and Justice Thomas joined in this dissent. Id. (Rehnquist, C.J., Scalia, J., and Thomas, J., dissenting).

98. 135 S. Ct. 2269 (2015). The Brumfield court acknowledged that "[I]ntellectually disabled persons may have "strengths in social or physical capabilities, strengths in some adaptive skill areas, or strengths in one aspect of an adaptive skill in which they otherwise show an overall limitation." Id. at 2281. Brumfield also held that a defendant needs "only to raise a 'reasonable doubt' as to his intellectual disability to be entitled to an evidentiary hearing." Id.; see also People v. Woodruff, 235 Cal. Rptr. 3d 513 (2018) (hearing that defendant received after guilty verdict for capital murder to determine whether he was intellectually disabled under Atkins did not deny his constitutional rights to due process and equal protection of the law, where jury trial devised by trial court was essentially identical to procedures stated in Atkins and statute governing hearings to determine intellectual disabilities). Brumfield is the only Fifth Circuit case that the Supreme Court has decided on this question.

99. Moore I, 137 S. Ct. 1039 (2017).

100. In Ex parte Briseno, Texas adhered to a standard that included seven evidentiary factors that it articulated without any citation "to any authority, medical or judicial." Moore I, 137 S. Ct. at 1046 (citing 135 S.W.3d 1 (Tex. Ct. Crim. App. 2004)). These seven "Briseno factors" are:

- Did those who knew the person best during the developmental stage-his family, friends, teachers, employers, authorities - think he was mentally retarded at that time, and, if so, act in accordance with that determination?

- Has the person formulated plans and carried them through or is his conduct impulsive?

- Does his conduct show leadership or does it show that he is led around by others?

- Is his conduct in response to external stimuli rational and appropriate, regardless of whether it is socially acceptable?

- Does he respond coherently, rationally, and on point to oral or written questions or do his responses wander from subject to subject?

- Can the person hide facts or lie effectively in his own or others' interests?

- Putting aside any heinousness or gruesomeness surrounding the capital offense, did the commission of that offense require forethought, planning, and complex execution of purpose?

Moore I, 137 S. Ct. at 1046 n.6, (citing Briseno, 135 S.W.3d, at 8-9). 
Amendment. ${ }^{101}$ In vacating the Texas state opinion, the Supreme Court rearticulated its finding in Hall that "adjudications of intellectual disability should be "informed by the views of medical experts," 102 and that the Briseno standards was "an invention ... untied to any acknowledged source." 103 After quoting its language in Hall that "[t]he Eighth Amendment is not fastened to the obsolete," 104 the Court in Moore I noted "Hall indicated that being informed by the medical community does not demand adherence to everything stated in the latest medical guide. But neither does our precedent license disregard of current medical standards." ${ }^{105}$

The state court erred, the Supreme Court concluded, by mistakenly "over-emphasiz[ing the defendant's] perceived adaptive strengths," rather than focusing on his "adaptive deficits." 106 Further the lower court's "attachment" to the Briseno factors "further impeded its assessment of Moore's adaptive functioning" as they "advanced lay perceptions of intellectual disabilities," noting that the medical profession "has endeavored to counter [such] lay stereotypes." 107 Although the Texas court had said it would abandon reliance on the Briseno evidentiary factors," 108 the Supreme Court concluded that "it seems to have used many of those factors in reaching its conclusion." 109 The state court continued, in spite of the Court's admonition in Moore I, to rely on "lay stereotypes of the intellectually disabled." 110

Some important strains emerge from the post-Atkins opinions in Hall and Moore. The focus on dignity in Hall-mentioned at

101. Moore I, 137 S. Ct. at 1044.

102. Id. (quoting Hall, $135 \mathrm{~S}$. Ct. at 2000).

103. Id., discussing Ex parte Briseno, 135 S.W. 3d 1 (Tex, Crim. Ct, App. 2004).

104. Moore I, 137 S. Ct. at 1048 (quoting Hall, 134 S. Ct. at 1992).

105. Id. at 1049 .

106. Id. at 1050 .

107. Id. at 1051 .

108. Ex parte Moore, 548 S.W. 2d at 560, rev'd E remanded, Moore II, 139 S. Ct. 666 (2019).

109. Moore II, 139 S. Ct. at 671 .

110. Moore I, 137 S. Ct. at 1052. By way of example, in rejecting the intellectual disability claim, the Texas court had stressed that Moore "had a girlfriend" and a job. Ex parte Moore, 548 S.W.2d at 570-71, rev'd 139 S. Ct. at 672. The Supreme Court contrasted these stereotypes with legal criteria articulated by the American Association on Intellectual and Developmental Disabilities, criticizing the "incorrect stereotypes" that persons with intellectual disability "never have friends, jobs, spouses, or children." Moore II, 139 S. Ct. at 672 (quoting Robert L. Schlalock et al., InTEllectual Disability: DEFinition, Classification, and SySTEMS OF SuPPORTS 151 (Am. Ass'n on Intell. and Developmental Disabilities ed., 11th ed. 2010)). 
least eight times in the course of the majority opinion-is of major significance. ${ }^{111}$ This development followed up the Supreme Court's focus on dignitarian values expressed in Atkins, in which the Court cited Trop v. Dulles ${ }^{112}$ for the proposition that "the basic concept underlying the Eighth Amendment is nothing less than the dignity of man ... . The Eighth Amendment must draw its meaning from the evolving standards of decency that mark the progress of a maturing society." 113 The Court's strong focus in Hall underscores its commitment to these principles. ${ }^{114}$

Moore is significant for multiple reasons. First, as it follows on the (more distant) heels of Atkins, and the (more recent) heels of Hall and Brumfield, it makes clear that the Supreme Court takes very seriously the potential peril of subjecting a person with intellectual disability to execution. ${ }^{115}$ Second, it reaffirms the Court's embrace of the most up-to-date professional standards in support of its constitutional discourse. ${ }^{116}$ Third, its focus on the way the Briseno factors

111. See generally Kevin Barry, The Death Penalty $\mathcal{E}^{2}$ the Dignity Clauses, 102 IowA L. REV. 383 (2017). Professor Carol Sanger has suggested that dignity means that people "possess an intrinsic worth that should be recognized and respected," and that they should not be subjected to treatment by the state that is inconsistent with their intrinsic worth. Carol Sanger, Decisional Dignity: Teenage Abontion, Bypass Hearings, and the Misuse of Law, 18 Colum. J. GENDER \& L. 409, 415 (2009). Treating people with dignity and respect makes them more likely to view procedures as fair and the motives behind law enforcement's actions as wellmeaning. Tamara Birckhead, Toward a Theory of Procedural Justice for Juveniles, 57 BUFF. L. REV. 1447, 1474 (2009). A notion of individual dignity—generally articulated through concepts of autonomy, respect, equality, and freedom from undue government interferencewas at the heart of a jurisprudential and moral outlook that resulted in the reform, not only of criminal procedure, but of the various institutions more or less directly linked with the criminal justice system, including juvenile courts, prisons, and mental institutions. Heather Ellis Cucolo \& Michael L. Perlin, Promoting Dignity and Preventing Shame and Humiliation by Improving the Quality and Education of Attorneys in Sexually Violent Predator (SVP) Civil Commitment Cases, 28 U. FLA. J. L. \& PUb. PoL'y 291, 301-02 (2017). On the relationship between dignity and therapeutic jurisprudence, see infra text accompanying notes 288-94.

112. 356 U.S. $86,100-01$ (1958).

113. Atkins, 536 U.S. at 311-12.

114. It is important to consider Justice Alito's curious dissent in Hall. His faux populist charge that the professional associations relied upon by the majority reflect nothing but a "small, professional elite," Hall v. Florida, 134 S. Ct. 1986, 2005 (1986) (Alito, J., dissenting), flies in the face of reality. At this point in time, there is not a shred of expert support that suggests that a strict numerical cutoff can or should be the "be all and end all" of assessing intellectual disability. Yet, he adheres to his rejection of all professional opinion (supported by all the valid and reliable research). Id.

115. See Austin Holler, Moore v. Texas and the Ongoing National Consensus Struggle Between the Eighth Amendment, the Death Penalty, and the Definition of Intellectual Disability, 50 LoY. U. CHI. L.J. 415, 434 (2018).

116. Id. at 438 . 
"advanced lay perceptions of intellectual disabilities" and how the medical profession "has endeavored to counter [such] lay stereotypes," $" 117$ tells us that the Court truly does take these issues seriously. ${ }^{118}$ As we note below, twenty-one failures in the Fifth Circuit are the direct result of that court's use of the since-discredited Briseno factors. ${ }^{119}$

Importantly for the purposes of this paper, Moore was relied upon by the Supreme Court in remands of four cases to the Fifth Circuit. ${ }^{120}$ Of these four, one resulted in actual relief, ${ }^{121}$ two are still being litigated, ${ }^{122}$ and one resulted in an execution. ${ }^{123}$

\section{The Data AND What IT Tells Us}

\section{A. Research Methodology}

In order to conduct the necessary data analysis, the authors searched Fifth Circuit cases invoking Atkins claims on both the LexisNexis and Westlaw databases. First, we conducted a general search of Atkins claims on both databases. Of these, only cases in which defendants relied upon Atkins for the purpose of seeking reversal or vacation of their death sentence due to an intellectual disability were included in the analysis. Likewise, cases that sought to expand Atkins to cover conditions other than intellectual disability, such as

117. Moore I, 137 S. Ct. at 1052; Moore II, 139 S. Ct. at 672.

118. See Perlin \& Cucolo, supra note 16, at $\$ 17-4.2 .4$ : "The Court (implicitly, to be sure) acknowledged how sanism-based predominantly upon stereotype, myth, superstition, and deindividualization, and sustained and perpetuated by our use of alleged 'ordinary common sense' (OCS) - permeates the death penalty fact-finding process." On sanism in general, see supra note 8. On false "ordinary common sense" in general, see infra note 198. 119. See supra note 100.

120. See Henderson v. Davis, 868 F.3d 314, 315 (5th Cir. 2017); Long v. Davis, 706 F. App'x 181, 181 (5th Cir. 2017); Weathers v. Davis, 915 F.3d 1025, 1026 (5th Cir. 2019); Martinez v. Davis, 137 S. Ct. 1432, 1433 (2017).

121. Henderson v. Davis, 868 F.3d 314, 315 (5th Cir. 2017). For earlier decisions, see In $r e$ Henderson, 462 F.3d 413, 417 (5th Cir. 2006); Henderson v. Thaler, 626 F.3d 773, 781 (5th Cir. 2010); see also Henderson v. Stephens, 791 F.3d 567, 586 (5th Cir. 2015).

122. Long v. Davis, 706 F. App'x 181 (5th Cir. 2017); Weathers v. Davis, 659 F. App'x 778 (5th Cir. 2016).

123. Martinez v. Davis, 653 F. App'x 308, 316-17 (5th Cir. 2016). 
fetal alcohol syndrome, ${ }^{124}$ brain damage, ${ }^{125}$ or mental illness, ${ }^{126}$ were also included in the collective analysis. Cases that raised Penry mitigation-based claims, competency claims, non-capital cases, and cases that only referred to Atkins to discuss rules for raising retroactive claims were omitted. ${ }^{127}$

Through this process, seventy defendants' cases were determined to involve Atkins claims. Inspired by the previously referenced Atkins "pressure points," ${ }^{28}$ a coding sheet made up of twenty variables was created (Appendix A). Each case was coded to determine which variables were present or absent. After reading through each case, it was possible to code the variables, and data was entered to develop frequency tables to determine the prevalence of these variables among the Atkins claims. An exploratory analysis was conducted to determine whether specific factors were related to successful, unsuccessful, and partially successful cases.

\section{B. Overview of Findings}

When we consider the entire universe of cases in which the Fifth Circuit has considered Atkins claims, ${ }^{129}$ some major findings emerge.

124. See, e.g., In re Soliz, 938 F.3d 200 (5th Cir. 2019); Soliz v. Davis, 750 F. App'x 282 (5th Cir. 2018).

125. See, e.g., Shore v. Davis, 845 F.3d 627 (5th Cir. 2017); Mays v. Stephens, 757 F.3d 211 (5th Cir. 2014); Tamayo v. Stephens, 740 F.3d 991 (5th Cir. 2014). For other litigation in the Tamayo case, see, e.g., Tamayo v. Perry, 553 F. App'x 395 (5th Cir. 2014); In re Tamayo, 552 F. App'x 371 (5th Cir. 2014); Tamayo v. Thaler, 2011 U.S. App. LEXIS 26665 (5th Cir. Dec. 21, 2011); Tamayo v. Thaler, 2011 U.S. App. LEXIS 26671 (5th Cir. Jan. 21, 2011). On the relationship between intellectual disability and brain injury in this context, see Alison J. Lynch, Michael L. Perlin \& Heather Ellis Cucolo, "My Bewildering Brain Toils in Vain": Traumatic Brain Injury and The Criminal Trial Process, 74 RuTGERs L. REV. - (2021) (forthcoming), draft accessible at https:// papers.ssrn.com/sol3/papers.cfm?abstract_id=3777551.

126. See, e.g., Johnson v. Davis, 935 F.3d 284 (5th Cir. 2019); Rockwell v. Davis, 853 F.3d 758 (5th Cir. 2017); Ward v. Stephens, 777 F.3d 250 (5th Cir. 2015); Turner v. Epps, 460 F. App'x 322 (5th Cir. 2012); Ripkowski v. Thaler, 438 F. App'x 296 (5th Cir. 2011); Shisinday v. Quarterman, 511 F.3d 514 (5th Cir. 2007); In re Neville, 440 F.3d 220 (5th Cir. 2006). For other cases involving defendants with fetal alcohol syndrome or mental illness, see infra note 258.

127. See, e.g., United States v. Torres, 717 F. App'x 450 (5th Cir. 2018); Panetti v. Davis, 863 F.3d 366 (5th Cir. 2017); In re Hunt, 835 F.3d 1277 (5th Cir. 2016); In re Williams, 806 F.3d 322 (5th Cir. 2015); Vasquez v. Thaler, 389 F. App'x 419 (5th Cir. 2010); Adams v. Quarterman, 324 F. App'x 340 (5th Cir. 2009).

128. See Perlin, Life Is in Mirrors, supra note 18, at 331-32; PERLIN \& CUCOLO, supra note 16 , at $\$ 17-4.2 .2$.

129. See supra Section III.A for a description of the methodology employed in this analysis. 
As we noted above, there was actual relief granted in only nine $(12.9 \%)$ of the cases, ${ }^{130}$ and eight cases $(11.5 \%)$ are still pending. ${ }^{131}$ In short, in only seventeen $(24 \%)$ of the cases did Atkins

130. See Henderson v. Davis, 868 F.3d 314 (5th Cir. 2017); Martinez v. Davis, 653 F. App'x 308 (5th Cir. 2016); Brumfield v. Cain, 808 F.3d 1041 (5th Cir. 2015); In re Campbell, 750 F.3d 523 (5th Cir. 2014); Pierce v. Thaler, 604 F.3d 197 (5th Cir. 2010); Wiley v. Epps, 625 F.3d 199 (5th Cir. 2010); Moore v. Quarterman, 342 F. App'x 65 (5th Cir. 2009); Thomas v. Quarterman, 335 F. App'x 386 (5th Cir. 2009); Bell v. Cockrell, 310 F.3d 330 (5th Cir. 2002). It is difficult to characterize Martinez and Wiley as "successes," as Martinez died in prison and Wiley died on death row. Campbell's case was ultimately resolved in federal court without an evidentiary hearing. The Attorney General hired an expert to review the extensive documentary evidence concerning Campbell's background, and apparently advised counsel that the defendant was likely to prevail on his Atkins claim; the state thus agreed to a stipulated order finding that the defendant had an intellectual disability. See Campbell v. Davis, Civ. No. 4:00-cv-03844 (S.D. Tex., May 10, 2019) (Joint Advisory Concerning Campbell's Intellectual Disability Claim on file with authors).

Campbell was subsequently re-sentenced to life in prison with the possibility of parole. He was reviewed in early 2018 for possible release on parole, and parole was officially denied on March 2, 2018, and was given a seven-year "set-off," meaning that his next parole review was scheduled for February 2025. See Parole Review Information, TEX. DEP'T OF CRIM. JUST., https:/ / offender.tdcj.texas.gov/OffenderSearch/reviewDetail action?sid=04286378

\&tdcj=02141630\&fullName=CAMPBELL\%2CROBERT+JAMES. His counsel believes the likelihood that Campbell will ever be released on parole is "very small." $\mathbf{E}$-mail from Robert Owen, Campbell's appellate counsel, to the authors (June 8, 2020, 11:20 AM) (on file with authors).

131. See Sorto v. Davis, 716 F. App'x 366 (5th Cir. 2018); In re Cathey, 857 F.3d 221 (5th Cir. 2017); Long v. Davis, 706 F. App'x 181 (5th Cir. 2017); Weathers v. Davis, 659 F. App'x 778 (5th Cir. 2016); Butler v. Stephens, 625 F. App'x 641 (5th Cir. 2015); In re Chase, 804 F.3d 738 (5th Cir. 2015); Rivera v. Quarterman, 505 F.3d 349 (5th Cir. 2007); In re Johnson, 334 F.3d 403 (5th Cir. 2003).

After the Fifth Circuit entered a stay of execution and authorized the successor petition, Johnson's case was remanded to the district court. His counsel filed a new habeas petition raising the Atkins claim, asking for a new hearing, and arguing that the defendant's intellectual disability is relevant to tolling (on the question of his diligence in pursuing his rights). See Johnson v. Davis, Civ. No. 4:19-CV-03047 (S.D. Tex., Nov. 12, 2019) (Amended Second or Successive Petition for Writ Of Habeas Corpus on file with authors). His lawyer believes the odds are "pretty good" that such a hearing will be scheduled. E-mail from Jessica Graf, Johnson's appellate counsel, to the authors (June 8, 2020, 12:44 PM) (on file with authors). Long recently had a state habeas evidentiary hearing; there has been no decision as of yet. E-mail from Scott Smith, Moore's appellate counsel, to the authors (June 8, 2020, 03:50 PM) (on file with authors). Counsel notes that Long's last four IQ tests were scored at 62, 63, 64 and 63, an "amazing consistency." Id. Appellate counsel has had no contact with Moore since that defendant's sentence was commuted. Email from Scott Smith, Moore's appellate counsel, to the authors (June 8, 2020) (on file with authors). See Moore v. Dretke, No. Civ.A. 603CV224, 2005 U.S. Dist. WL 1606437 (E.D. Tex. July 1, 2005). Pierce is currently serving a life sentence, his death sentence having been vacated after a determination of a Strickland $v$. Washington violation, see Perlin, Harmon \& Chatt, supra note 7 , at 296; see also E-mail from David Dow, Pierce's appellate counsel, to the authors (June 8, 2020, 11:19 AM) (on file with authors).

The post-litigation history of the Rivera case is the most complex of any in this cohort. The district court agreed to abate the case so that counsel could seek a commutation of the 
matter at all to the defendants in question. ${ }^{132}$ And, importantly, in thirteen cases (nearly $18.5 \%$ ), in which some preliminary relief had been granted, defendants were nonetheless executed or are awaiting execution. ${ }^{133}$ In the context of the universe of "total failures," two factors stand out: of the forty "total failures," twenty-one turned, at least in significant part, on the Fifth Circuit's use of the subsequently-discredited Briseno factors, ${ }^{134}$ and in the twenty-two cases in

defendant's sentence. Counsel filed a request with the Texas Board of Pardons and Paroles, and that board unanimously agreed that defendant's sentence should be commuted to life without parole based on his intellectual disability. Counsel asked Governor Rick Perry to commute his sentence (as part of the commutation process in Texas, the Governor must agree to commutation). Over a six-year period, this was never acted upon by then-Governor Perry. Although the trial judge administratively abated the case in 2014, since Governor Abbott took office in 2015, the defendant has remained on death row (but without an execution date since 2003). The district judge recently issued an Order on May 11, 2020 asking whether we should go forward with a hearing on equitable tolling. Counsel then (1) sent a letter to Governor Abbott on May 23, 2020, asking to have Mr. Rivera's sentence commuted to life without parole, and (2) filed a Joint Advisory with the district court, informing the court of these proceedings, and asking the court to give the Governor time to act. In light of the decision of the Texas Court of Criminal Appeals in Ex Parte Moore, 587 S.W.3d 787 (Tex. Ct. Crim. App. 2019), counsel remains "hopeful" that Governor Abbott will commute Rivera's sentence. E-mail from Cathy Smith, Rivera's appellate counsel, to the authors (June 8, 2020, 05:21 PM) (on file with authors).

In the Sorto case, counsel has obtained funding to do additional testing on the question of intellectual disability. Email from David Dow, Pierce's appellate counsel, to the authors (June 8, 2020, 11:19 AM) (on file with authors).

In Weathers, counsel is working on a state successor petition, following remand from Supreme Court on basis of that Court's decisions in Moore z. Texas. E-mail from John "Bud" Ritenour, Weathers' current counsel, to the authors (July 13, 2013, 10:13 PM) (on file with authors).

132. In addition to cases discussed on the merits elsewhere in this paper, see, e.g., Hearn v. Thaler, 669 F.3d 265 (5th Cir. 2012) (relying on Briseno); Ladd v. Stephens, 748 F.3d 637 (5th Cir. 2014) (same); Lewis v. Thaler, 701 F.3d 783 (5th Cir. 2012) (same); Wilson v. Thaler, 450 F. App'x 369 (5th Cir. 2011) (same); Woods v. Quarterman, 493 F.3d 580 (5th Cir. 2007) (same); Rosales v. Quarterman, 291 F. App'x 558, 562-63 (5th Cir. 2008) (Atkinsbased COA granted out of "abundance of caution"; subsequently dismissed as defendant did not submit sufficient evidence to court). This entire cohort of cases reflect cases that appeared first to be "partial successes," but eventually were failures.

133. See infra Appendix B.

134. See Moore I, 137 S. Ct. 1039, 1044-46 (2017). On retroactivity, in the Sixth Circuit, see Hill v. Anderson, 881 F.3d 483, 492 (6th Cir. 2018), vacated by Shoop v. Hill, 139 S. Ct. 504 (2019) (Moore is not to be applied retroactively). See also Smith v. Comm'r, Alabama Dep't of Corr., 924 F.3d 1330 (11th Cir. 2019), cert. denied, 2020 WL 3578738 (2020) (ruling that the constitutional law announced in Moore $v$. Texas that states could not disregard current clinical and medical standards in assessing whether capital defendant was intellectually disabled did not apply retroactively). The twenty-one cases were: Henderson, 868 F. 3d at 314, vacated, 137 S. Ct. 1450 (2017); Eldridge v. Davis, 661 F. App'x 253 (5th Cir. 2016); Segundo v. Davis, 831 F.3d 345 (5th Cir. 2016); Guevara v. Stephens, 577 F. App'x 364 (5th Cir. 2014), cert. denied, 575 U.S. 986 (2019), with further proceedings in Guevara v. Davis, 679 F. App'x 332 (5th Cir. 2019), cert. denied, 138 S. Ct. 554 (2019); Garcia v. 
which claims under Strickland $v$. Washington were raised, there were partial successes in only three. ${ }^{135}$

When looking more closely at the universe of ostensible "successes," important findings emerge. If a defense expert had adequately explained why malingering could be ruled out, if an expert who explained the significance of the Flynn Effect, or if the WAIS III and WAIS-R tests were used in evaluating the defendant, it is more likely that there would be "success" at the Fifth Circuit level. ${ }^{136}$ On the other hand, if the WISC test were used, or if defense counsel failed to introduce expert testimony to rebut the notion that the defendant malingered on IQ tests, it was less likely that there would be "success" at the Fifth Circuit level (or at the district court level). ${ }^{137}$

Next, we discuss the key variable factors-malingering, the Flynn Effect and the various IQ tests-and then consider that small universe of cases in which defense counsel dealt with each of these effectively, a strategy leading in some cases to actual relief.

Stephens, 757 F.3d 220 (5th Cir. 2014); Mavs v. Stephens, 757 F.3d 211 (5th Cir. 2014); Williams v. Stephens, 761 F.3d 561 (5th Cir. 2014); Harris v. Thaler, 464 F. App'x 301 (5th Cir. 2012); Blue v. Thaler, 665 F.3d 647 (5th Cir. 2011); Chester v. Thaler, 666 F.3d 340 (5th Cir. 2011); Hines v. Thaler, 456 F. App'x 357 (5th Cir. 2011); Esparza v. Thaler, 408 F. App'x 787 (5th Cir. 2010); Moore v. Quarterman, 517 F.3d 781 (5th Cir. 2008); Perkins v. Quarterman, 254 F. App'x 366 (5th Cir. 2007); Taylor v. Quarterman, 498 F.3d 306 (5th Cir 2007); Clark v. Quarterman, 457 F.3d 441 (5th Cir. 2006); In re Brown, 457 F.3d 392 (5th Cir. 2006); In re Salazar, 443 F.3d 430 (5th Cir. 2006); Moreno v. Dretke, 450 F.3d 158 (5th Cir. 2006); United States v. Webster, 421 F.3d 308 (5th Cir. 2005).

135. See Busby v. Davis, 925 F.3d 699 (5th Cir. 2019); Butler v. Stephens, 625 F. App'x 641 (5th Cir. 2015); Pierce v. Thaler, 604 F.3d 197 (5th Cir. 2010).

136. Defense counsel was "successful" in four of nine (44.4\%) cases in which she or he presented rebuttal to state-introduced evidence of "malingering," in five of the nine cases $(55.5 \%)$ in which s/ he presented evidence on the Flynn Effect and in eight of nine $(88.9 \%)$ in which s/he presented evidence that the WAIS IQ test was used. See Appendix B, where "successful" is used to denote cases in which actual relief was granted or ordered.

137. Thus, where Strickland $v$. Washington claims were raised, defendants were successful only in two of twenty cases, or nine percent. See infra note 266. On the Fifth Circuit and Strickland claims in general, see Perlin, Harmon \& Chatt, supra note 7. In cases in which the WISC IQ test, rather than the WAIS IQ test, was used, defendants have thus far been successful in none of the thirteen cases. See infra note 169. There is one case in this category in which litigation is still ongoing in which the defendant remains potentially successful. See Butler v. Stephens, 625 F. App'x 641 (5th Cir. 2015), discussed in Appendix C. On the other hand, where the WAIS test was used, defendants were successful in thirteen out of thirtynine-thirty-three percent of cases. See Appendix B. 


\section{i. On Malingering}

It is important to first consider how allegations of malingering are construed. ${ }^{138}$ In spite of the unanimity of the valid and reliable evidence that malingering is (1) ultra-rare in cases involving intellectual disability, and (2) easy to detect, ${ }^{139}$ allegations of malingering persist in the data base of the cases we have studied. The Fifth Circuit has_perhaps with "willful blindness" 140 _accepted these allegations, ${ }^{141}$ in almost all cases (except, as we have noted, where it is rebutted by expert testimony), and that rebuttal is combined with discussion of the Flynn Effect and the use of the WAIS IQ test. ${ }^{142}$ As noted above, in his Atkins dissent, Justice Scalia warned that "the symptoms of this condition can readily be feigned ... [and that] the capital defendant who feigns mental retardation risks

138. See generally PERLIN \& CuCOLO, supra note 16, \$ 2-3.3.1, at 2-29 to 2-31.

139. See, e.g., Richard Rogers, R. Michael Bagby \& S.E. Dickens, SiRS: StRuctured INTERVIEW OF REPORTED SYMPTOMS: PROFESSIONAL MANUAL (1992); see also, e.g., Richard Rogers et al., Explanatory Models of Malingering, 18 LAW \& HUM. BEHAV. 543 (1994); William Wilkinson, Therapeutic Jurisprudence and Workers' Compensation, 30 ARIz. ATT'y 28, 29 n.12 (April 1994) (citing Richard Rogers et al., Feigning Neuropsychological Impairment: A Critical Review of Methodological and Clinical Considerations, 13 CLINICAL PSYCH. REV. 255 (1993)); David R. Katner, Raising Mental Health Issues-Other than Insanity-in Juvenile Delinquency Defense, 28 Am. J. CRIM. L. 73, 90 n.101 (2000) (citing inter alia Shayna Gothard et al., Detection of Malingering in Competency to Stand Trial Evaluations, 19 LAW \& HUM. BEHAV. 493 (1995) (as cited in Perlin, Simplify, supra note 74, at 635 n.123.)); Michael L. Perlin, Unpacking the Myths: The Symbolism Mythology of Insanity Defense Jurisprudence, 40 CASE W. RES. L. REV. 599, 715-16 nn.556-58 (1989-90).

140. There is "willful blindness" when individuals "deliberately shield ... themselves from clear evidence of critical facts that are strongly suggested by the circumstances." Global-Tech Appliances, Inc. v. SEB S.A., 563 U.S. 754, 766 (2012).

141. On how courts/decisions do not concern themselves with such underlying issues in the criminal trial process is a prime example of such willful blindness, see Michael L. Perlin, Pretexts and Mental Disability Law: The Case of Competency, 47 U. MIAMI L. ReV. 625, 658-59 (1993). Further, on how this sort of willful blindness is the result of "courts' succumbing to the vividness heuristic," see Michael L. Perlin, Deborah A. Dorfman \& Naomi M. Weinstein, "On Desolation Row": The Blurring of the Borders between Civil and Criminal Mental Disability Law, and What It Means for All of Us, 24 TEx. J. ON CIV. LIBS. \& CIV. RTS. 59, 85-86 (2018). The "vividness heuristic" is a cognitive-simplifying device through which a "single vivid, memorable case overwhelms mountains of abstract, colorless data upon which rational choices should be made." Perlin, Borderline, supra note 74, at 1417.

142. See infra Section II.C. 
nothing at all. ${ }^{143}$ This fear, a close relation to the fear of faked insanity defenses, ${ }^{144}$ continues to "paralyze the legal system." 145

Strikingly, in a parallel area-that of incompetency to stand trial cases-courts continue to focus, almost obsessively, on testimony that raises the specter of malingering, ${ }^{146}$ notwithstanding other evidence that such feigning is attempted in less than eight percent of all such cases. ${ }^{147}$ There is no evidence whatsoever that such feigning "has ever been a remotely significant problem of criminal procedure," especially in cases of defendants with intellectual disabilities. ${ }^{148}$

Importantly, valid and reliable instruments that expose feigned malingering have been available to researchers for years and have been written about extensively in articles in databases that are readily available to Supreme Court justices. ${ }^{149}$ As of twenty years ago, over ninety percent of all subjects were correctly classified as

143. Atkins, 536 U.S. at 353. Here, Justice Scalia cited merely to Hale's Pleas of the Crown. Matthew Hale, 1 PleAs OF THE CROWN 33-34 (1st Am. ed. 1847). As noted above, an earlier exhaustive empirical analysis has found this fear to be "unfounded." See supra note 74; Blume et al., An Empirical Look, supra note 36, at 639.

144. See, e.g., Michael L. Perlin, "For the Misdemeanor Outlaw": The Impact of the ADA on the Institutionalization of Criminal Defendants with Mental Disabilities, 52 ALA. L. REV. 193, 236 (2000); see also Perlin, Neuroimaging Testimony, supra note 48, at Error! Main Document Only. 907 .

145. Perlin, Borderline, supra note 74, at 1423. Again, Professors John Blume and his colleagues state bluntly-and accurately-"Justice Scalia was wrong." Blume et al., A Tale of Two Atkins, supra note 74, at 396 . The authors note that in calculating the filing rate "in the manner most generous to Justice Scalia's floodgates concern . . only approximately $7.7 \%$ of persons whose lives could potentially be spared by a determination of intellectual disability have raised such claims." See id. at 396-98.

146. See, e.g., State v. Evans, 586 N.E.2d 1042 (Ohio 1992), cert. denied, 506 U.S. 886 (1992); State v. Sharkey, 821 S.W.2d 544, 546 (Mo. Ct. App. 1991).

147. Dewey Cornell \& Gary Hawk, Clinical Presentation of Malingerers Diagnosed by Experienced Forensic Psychologists, 13 LAW \& HUM. BEHAV. 375, 380-83 (1989). On the potential role of racial bias in such determinations, see id. at 382 (clinicians may over-diagnose malingering in black defendants). See generally Michael L. Perlin \& Heather Ellis Cucolo, "Tolling for the Aching Ones Whose Wounds Cannot Be Nursed": The Marginalization of Racial Minorities and Women in Institutional Mental Disability Law, 20 J. GENDER, RACE \& JUST. 431 (2017) [hereinafter Perlin \& Cucolo, Tolling]; James Hicks, Ethnicity, Race, and Forensic Psychiatry: Are We Color-Blind?, 32 J. AM. ACAD. PSYCHIATRY L. 21 (2004).

148. See, e.g., Douglas Mossman, Atkins v. Virginia: A Psychiatric Can of Worms, 33 N.M. L. REV. 255, 276 (2003) (concluding that mental retardation (as it was then known) was "hard to fake successfully, because the criteria require evidence that retardation began during childhood-evidence, that is, that the condition existed years before the defendant committed a capital crime.").

149. See supra note 74 and accompanying text. 
either faking or not faking. ${ }^{150}$ As Professor James Ellis and his colleagues have noted:

Successfully feigning a lower level of intelligence on IQ tests is more difficult than jurors and, apparently, judges on the Fifth Circuit, imagine. A major reason is the structure of the tests themselves. "During IQ testing, malingerers will frequently miss 'easy' questions but answer more difficult questions correctly. Their test results often show wide 'scatter' and inconsistent responding." 151

\section{ii. The Flynn Effect. ${ }^{152}$}

The Flynn Effect refers to a theory in which the intelligence of a population increases over time, thereby potentially inflating performance on IQ examinations. ${ }^{153}$ The accepted increase in scoring is approximately three points per decade or 0.33 points per year. ${ }^{154}$ As many courts have already recognized, Hall does not mention the Flynn Effect and does not require its application to all IQ scores in Atkins cases. ${ }^{155}$ Although the American Association on Intellectual and Developmental Disabilities' publication, The Death Penalty and Intellectual Disability ${ }^{156}$ may now advocate for the

150. David Schretlen \& Hal Arkowitz, A Psychological Test Battery to Detect Prison Inmates Who Fake Insanity or Mental Retardation, 8 BEHAV. SCI. \& THE L. 75 (1990).

151. Ellis, Everington \& Delpha, supra note 14, at 1370 n.261 (quoting, in part, Philip J. Resnick \& Michael R. Harris, Retrospective Assessment of Malingering in Insanity Defense Cases, in Retrospective Assessment of Mental States in Litigation: Predicting the Past 101, 126 (Robert I. Simon \& Daniel W. Shuman eds., 2002)).

152. See generally PERLIN \& CuCOLO, supra note 16, § 17-4.2.2. n.688.01, at 17-104.

153. Quince v. State, 241 So.3d 58, 60 n.2 (Fla. 2018).

154. See id.; see, e.g., James R. Flynn, Massive IQ Gains in 14 Nations: What IQ Tests Really Measure, 101 Psychol. BulL. 171, 172-77 (1987) (discussing the implications of the Flynn Effect, which refers to observed gains in IQ scores over time); Young, supra note 26 (discussing the determinations of intellectual disability in death penalty cases).

155. See, e.g., Black v. Carpenter, 866 F.3d 734, 746 (6th Cir. 2017) (noting that Hall does not even mention the Flynn effect and does not require that IQ scores be adjusted for it), cert. denied, 138 S. Ct. 2603 (2018); Smith v. Duckworth, 824 F.3d 1233, 1246 (10th Cir. 2016), cert. denied, 137 S. Ct. 1333 (2017) ("Hallsays nothing about application of the Flynn Effect to IQ scores in evaluating a defendant's intellectual disability"); Ledford v. Warden, Ga. Diagnostic \& Classification Prison, 818 F.3d 600, 639 (11th Cir. 2016), cert. denied, 137 S. Ct. 1432 (2017) ("Hall did not mention the Flynn effect. . . There is no "established medical practice' of reducing IQ scores pursuant to the Flynn effect. The Flynn effect remains disputed by medical experts, which renders the rationale of Hall wholly inapposite.").

156. The Death Penalty and Intellectual Disability (Edward A. Polloway, ed. 2015). See Quince, 241 So.3d at 61-62. 
adjustment of all IQ scores in Atkins cases that were derived from tests with outdated norms to account for the Flynn Effect, "Hall indicated that being informed by the medical community does not demand adherence to everything stated in the latest medical guide." ${ }^{157}$ The Fifth Circuit has never endorsed the use of the Flynn Effect in death penalty cases. ${ }^{158}$

\section{iii. The Different IQ Tests}

The IQ test that was most commonly used in these seventy cases was the Wechsler Adult Intelligence Scale (III or IV). While over half $(55.7 \%)$ of cases used the full-scale form of this test, fewer than one-quarter $(22.9 \%)$ of cases analyzed either used the WAIS-R concurrently or used this shortened form instead. These tests have often been considered to be the "gold standard" for testing intellectual capacity in both clinical settings and criminal courts. ${ }^{159}$

157. Moore I, 137 S. Ct. at 1049.

158. See In re Cathey, 857 F.3d 221, 227 n.33 (5th Cir. 2017) ("This Court has routinely declined to address Flynn Effect arguments, typically reciting some version of the following: 'the Flynn Effect "has not been accepted in this Circuit as scientifically valid."'); see also Gray v. Epps, 616 F.3d 436, 446 n.9 (5th Cir. 2010) (quoting In re Mathis, 483 F.3d 395, 398 n.1 (5th Cir. 2007)) ("Importantly, however, nor has the Flynn Effect been rejected. . . We also note the Eleventh Circuit's recent conclusion that district courts, upon their consideration of the expert testimony, may apply or reject the Flynn Effect, which is a finding of fact reviewed for clear error."); Ledford v. Warden, Georgia Diagnostic \& Classification Prison, 818 F.3d 600, 640 (11th Cir. 2016); Walker v. True, 399 F.3d 315, 322-23 (4th Gir. 2005) (directing district court to consider Flynn Effect evidence).

159. David E. Hartman, Wechsler Adult Intelligence Scale IV (WAIS IV): Return of the Gold Standard, 16 Applied Neuropsychology 85, 85-87 (2009); see John Matthew Fabian, William W. Thompson \& Jeffrey B. Lazarus, Life, Death, and IQ: It's Much More than Just a Score. Understanding and Utilizing Forensic Psychological and Neuropsychological Evaluations in Atkins Intellectual Disability/Mental Retardation Cases, 59 CLEv. ST. L. Rev. 399, 413 (2011) ("the WAIS-IV is the most current version of the WAIS tests and should be used in Atkins evaluations"). On the differences between the WAIS-R and the WAIS-III tests, see Suzanne Fitzgerald, Nicola S. Gray \& Robert J. Snowden, A Comparison of WAIS-R and WAIS-III in the Lower IQ Range: Implications for Leaming Disability Diagnosis, $20 \mathrm{~J}$. APPLIED Res. IN INTELL. DISABILITIES 323 (2007). In death penalty cases, expert witnesses invariably refer to this test as the "gold standard." See, e.g., United States v. Roland, 281 F.Supp.3d 470, 504 n.49 (D.N.J. 2017) ("See, e.g., D.E. No. 386, Tr. at 54 (Dr. Hunter testifying that there is very little dispute that the WAIS is the 'gold standard' IQ test); D.E. No. 422, Tr. at 178 (Dr. Bigler testifying that WAIS is the "gold standard')"); United States v. Smith, 790 F. Supp. 2d. 482, 491 (E.D. La. 2011) ("the WAIS-III is a gold standard for [intelligence] testing"); cf. United States v. Montgomery, 2014 WL 1516147, *26 (W.D. Tenn. 2014) ("Expert witnesses for both Defendant and the Government described the Wechsler family of $\mathrm{IQ}$ tests-including the Wechsler Intelligence Scale for Children, Revised ("WISC-R") and the Wechsler Adult Intelligence Scale, Fourth Edition ("WAIS IV") —as the 'gold standard' in intelligence testing."). 
However, a 2011 study found that the Stanford-Binet ("SB5") IQ test scores are consistently lower than full scale scores given by the WAIS, with a mean difference of 16.7 points. ${ }^{160}$ Silverman and his colleagues believed that this difference may be due to the WAIS underestimating intellectual impairment. ${ }^{161}$

Strikingly, only one of the defendants whose cases are reviewed in this article that proffered evidence of the Wechsler Adult Intelligence Scale for Children (WISC) was potentially successful. ${ }^{162}$ Also developed by David Wechsler, this IQ test is supposed to deliver a score that is comparable to the WAIS tests, with the only key difference being that the WISC is created to measure childhood intelligence scores. ${ }^{163}$ However, prior research has found scores on the WISC-IV to be, on average, 11.82 points lower than scores on the WAIS-III in a sample of sixteen-year-old special education students. ${ }^{164}$ Other studies have contrastingly found the WAIS to consistently produce lower IQ scores than the WISC. ${ }^{165}$

The reason WISC scores are often used in cases involving Atkins claims is that this test is a well-accepted method for gauging a defendant's IQ prior to the age of eighteen. ${ }^{166}$ This is important because in order for defendants to prove that the existence of an intellectual disability that would qualify for death penalty exemption, they must be able to prove that their disability had its onset before the age of eighteen. ${ }^{167}$ Since the WISC, as suggested by Gordon and her colleagues and by Hannon and Kicklighter, does not have consistent findings that can be compared to a defendant's current IQ score, one may conclude that despite popular belief, the WISC would be an inadequate measures of juvenile IQ. ${ }^{168}$

160. Wayne Silverman et al., Stanford-Binet and WAIS IQ Differences and Their Implications for Adults with Intellectual Disability (aka Mental Retardation), 38 InTELLIGENCE 242, 242 (2010).

161. Id. at 248.

162. See generally Butler v. Quarterman, 576 F. Supp. 2d 805, 811-12 (S.D. Tex. 2008), aff'd in part $\mathcal{E}$ vacated in part on other grounds sub. nom, Butler v. Stephens, 625 F. App'x 641 (5th Cir. 2015).

163. Shirley Gordon et al., Comparison of the WAIS-III and WISC-IV in 16-Year-Old Special Education Students, 23 J. APPL. Rsch. IN INTELL. DiSABILITIES 197, 197 (2010).

164. Id.

165. See generally John E. Hannon \& Richard Kicklighter, WAIS versus WISC in Adolescents, 35 J. Consult. \& Cuin. Psychol. 179-182 (1970).

166. See generally Bruce Frumkin, Challenging Expert Testimony on Intelligence and Mental Retardation, 34 J. PSYCHIATRY \& L. 51, 53-55 (2006).

167. See Atkins, 536 U.S. at 308 n.3.

168. Gordon et al., supra note 163; Hannon \& Kicklighter, supra note 165. 
Even though the WISC was used in $18.6 \%$ of the cases considered in this article, only one of these cases may turn out to be successful in granting some form of preliminary relief. ${ }^{169}$ Furthermore, five of these defendants actually had higher WISC scores than their WAIS scores. ${ }^{170}$ All other defendants had similar scores between these two tests or did not have these scores reported. ${ }^{171}$

Although, as already noted, the WAIS is considered to be the "golden standard" for testing a defendant's IQ, Silverman and his colleagues have suggested that "the WAIS might systematically underestimate severity of intellectual impairment." 172 These researchers compared seventy-four adults diagnosed with intellectual disability and found that, in every participant tested, their WAIS Full Scale IQ was higher than their Stanford-Binet Composite IQ. ${ }^{173}$ The mean difference between the scores achieved on the WAIS and the scores achieved on the Stanford-Binet was an astonishing 16.7 points. ${ }^{174}$ In order to determine which of these tests had a more accurate measure of intelligence, Silverman and his colleagues compared their results to the results of other tests aimed at assessing intelligence, such as the Vineland Adaptive Behavior Scale, the WISC, the Leiter, and the Slosson tests of intelligence. ${ }^{175}$ Despite

169. See Butler v. Stephens, 625 F. App'x 641 (5th Cir. 2015); Matamoros v. Stephens, 783 F.3d 212 (5th Cir. 2015); Garcia v. Stephens, 757 F.3d 220 (5th Cir. 2014); Chester v. Thaler, 666 F.3d 340 (5th Cir. 2011); Hines v. Thaler, 456 F. App'x 357 (5th Cir. 2011); Mathis v. Thaler, 616 F.3d 461 (5th Cir. 2010); Williams v. Thaler, 602 F.3d 291 (5th Cir. 2010); Simpson v. Quarterman, 341 F. App'x 68 (5th Cir. 2009); Hall v. Quarterman, 534 F.3d 365 (5th Cir. 2008); In re Taylor, 298 F. App'x 385 (5th Cir. 2008); Moore v. Quarterman, 517 F.3d 781 (5th Cir. 2008); In re Lewis, 484 F.3d 793 (5th Cir. 2007); Woods v. Quarterman, 493 F.3d 580 (5th Cir. 2007). Butler was the only one of these cases that may, potentially, be a success. See Appendix C.

170. Garcia, 757 F.3d at 224; Mathis, 616 F.3d at 461; Hall, 534 F.3d at 365; In re Taylor, 298 F. App'x at 385; Woods, 493 F.3d at 580.

171. See Butler v. Stephens, 625 F. App'x 641 (5th Cir. 2015); Matamoros v. Stephens, 783 F.3d 212 (5th Cir. 2015); Chester v. Thaler, 666 F.3d 340 (5th Cir. 2011); Hines v. Thaler, 456 F. App'x 357 (5th Cir. 2011); Williams v. Thaler, 602 F.3d 291 (5th Cir. 2010); Simpson v. Quarterman, 341 F. App'x 68 (5th Cir. 2009); Moore v. Quarterman, 517 F.3d 781 (5th Cir. 2008); In re Lewis, 484 F.3d 793 (5th Cir. 2007). See Appendix C for more information.

172. Silverman et al., supra note 160 , at 242.

173. Id. at 244 .

174. Id.

175. Id. at 243, 245-46. See Cameron R. Pepperdine \& Adam W. McCrimmon, Test Review: Vineland Adaptive Behavior Scales, Third Edition (Vineland-3) by Sparrow, S. S., Cicchetti, D. V., $\mathcal{E}$ Saulnier, C. A., 33 CAN. J. SCH. PSYCHOL. 157 (2018) (describing and reviewing the Vineland test); Isaac L. Woods Jr. et al., What Is in a Name? A Historical Review of Intelligence Test Score Labels, 37 J. Psychoeducational Assessment 692 (2019) (discussing the Leiter 
having a more limited data set, it was determined that the StanfordBinet was consistently more comparable to the scores achieved on these tests than the WAIS. ${ }^{176}$ For instance, Silverman and his colleagues concluded that "while there was no difference between Stanford-Binet and Vineland scores, $t(14)=0.22, p>0.8$, WAIS scores were significantly higher than their Vineland counterparts, $t(16)=6.74, p<.00001 "(2010) .{ }^{177}$ Therefore, according to this research, the WAIS seems to produce consistently higher IQ scores than other tests aside from the WISC.

In sum, the introduction of the WAIS test (in numerous versions) was significantly related to a successful outcome, and contrarily, the introduction of the WISC test almost always produced an unsuccessful outcome in these cases. ${ }^{178}$

\section{The Successes: The "trifecta" of factors making actual relief more likely: the rebuttal of malingering, the mention of the Flynn Effect, and the use of the WAIS test.}

The use of three factors (1) malingering rebuttal, (2) reference to the Flynn Effect, and (3) use of the WAIS test were significantly related to a successful outcome. If these three factors were all present, ${ }^{179}$ it was more likely that defendants would prevail. There were seven cases in which all three factors were present, two of which were cases where defendants were re-sentenced to life in

and Slosson intelligence examinations); see also Sheri Lynn Johnson et al, Protecting People with Intellectual Disability from Wrongful Execution: Guidelines for Competent Representation, 46 HOFSTRA L. REV. 1107, 1120 n.63 (2018) (characterizing the Slosson test as not a reliable measure of IQ).

176. Silverman et al., supra note 160 , at 245 .

177. Id. at 246.

178. See supra note 137 (discussing Butler v. Stephens, 625 F. App'x 641 (5th Cir. 2015)).

179. We are here using the word "present" broadly. Thus, whereas there is no mention of malingering or the Flynn effect in the Fifth Circuit opinion In re Chase, 804 F.3d 738 (5th Cir. 2015), the opinion appears to adopt, for these purposes, the reasoning of an earlier state case, Chase v. State, 171 So.3d 463 (Miss. 2015), in which the latter court had stressed that "a circuit court should not rely on unsupported testimony of malingering at variance with the results of malingering tests," noting that "Chase met his burden of proof of subaverage intellectual functioning." Id. at 480-81. Similarly, the District Court in Butler v. Quarterman, 576 F. Supp. 2d 805, 812 (S.D. Tex. 2008), had noted there was no evidence of malingering. Also, in an earlier proceeding in Weathers v. Davis, 659 F. App'x 778 (5th Cir. 2016), the court had noted that there was testimony that a defense witness did not believe that the defendant was malingering. Weathers v. Stephens, 2015 WL 5098872, * 14 (E.D. Tex. 2015). 
prison. ${ }^{180}$ In one case, execution was barred ${ }^{181}$ and three cases are pending further developments. ${ }^{182}$ In just one case of these seven has an execution been scheduled. ${ }^{183}$ Although these findings do not reflect either causation or correlation, they prove that a significant relationship exists between the independent factors and case outcomes.

Thus, by way of example, in Brumfield $\%$. Cain, ${ }^{184}$ an expert "ruled out malingering as a possible explanation for Brumfield's IQ scores," 185 (on WAIS tests administered by both the defense and state experts), ${ }^{186}$ and the opinion discusses the possible impact of the Flynn effect as well. ${ }^{187}$ In Wiley v. Epps, ${ }^{188}$ the defendant was given WAIS tests ${ }^{189}$ and an expert explained the significance of the Flynn effect. ${ }^{190}$ The court concluded that "each of the experts who testified at the evidentiary hearing conducted testing to probe for

180. Brumfield v. Cain, 808 F.3d 1041, 1066 (5th Cir. 2015); Moore v. Quarterman, 342 F. App'x. 65, 65 (5th Cir. 2009).

181. Wiley v. Epps, 625 F.3d 199 (5th Cir. 2010). This defendant, however, died in prison awaiting further proceedings. See Susy Dahmer, Comment to Mississippi Prison and Jail Specific Discussions, PRISON TALK (July 5, 2011, 11:43 AM), http://www.prisontalk.com/ forums/showthread.php?t=552638.

182. The Chase defendant demonstrated that he met the statutory requirements to file a successive habeas application. In $r e$ Chase, 804 F.3d 738 (5th Cir. 2015). Weathers' case has been remanded to state trial court for a new hearing in light of Moore II. Email from John "Bud" Ritenour, Weathers' current counsel, to the authors (July 13, 2020) (on file with authors); Weathers v. Davis, 659 F. App'x 778 (5th Cir. 2016). In Butler, the District Attorney's office has agreed to new IQ testing (now postponed because of prison closure due to COVID-19), and agrees that, if Butler's score is seventy-five or below, he will agree to a resentencing. Ex parte Butler, No. WR-41, 121-03 (Tex. Crim. Ct. App., Sept. 18, 2019), on Application for Writ of Habeas Corpus, Cause No. 511112 in the 185th District Court; Butler v. Stephens, 625 F. App'x 641 (5th Cir. 2015), on remand from 600 F. App'x 246 (5th Cir. 2015).

183. See Busby v. Davis, 925 F.3d 699 (5th Cir. 2019). The execution had been scheduled for May 6, 2020 but was postponed because of COVID-19. See Execution of Texas inmate convicted of killing professor, 77, delayed, KW'TX (Apr. 28, 2020, 2:48 PM),

https://www.kwtx.com/content/news/Execution-of-Texas-inmate-convicted-of-killing-professor-77-delayed-570014061.html.

184. 808 F.3d 1041 (5th Cir. 2015).

185. Id. at 1047 n.8.

186. Id. at $1047-48$.

187. Id. at $1060 \mathrm{n} .27$ (noting that it "was not necessary to decide whether to recognize the Flynn effect in this case, however, as Brumfield's scores satisfy the first prong of the intellectual disability test without a Flynn effect adjustment").

188. 625 F.3d 199 (5th Cir. 2010).

189. Id. at 202-03.

190. Id. at 203. 
malingering. ${ }^{191}$ Dr. O'Brien, Dr. Swanson, and Dr. Macvaugh each indicated that there was no evidence that Wiley was feigning or malingering intellectual or adaptive functioning deficits. ${ }^{192}$ And, in Busby v. Davis, ${ }^{193}$ in which defendant had been given the WAIS test, ${ }^{194}$ the court considered the impact of the Flynn effect and the fact that the defense expert found no malingering, ${ }^{195}$ in holding that reasonable jurists could debate whether the district court had properly denied habeas petitioner's Atkins claim, that he was intellectually disabled and thus ineligible for execution, so that a certificate of appealability was warranted. ${ }^{196}$

\section{The Failures: The Fifth Circuit's Global Errors}

It is important here to specifically consider cohorts of cases in which the Fifth Circuit-clearly and beyond doubt-relied on false science ${ }^{197}$ and false "ordinary common sense" 198 to reject defendants' Atkins claims. These cases reflect its obsessive fear of defendants successfully malingering intellectual disability, ${ }^{199}$ its

\footnotetext{
191. Id. at 221.

192. Id at 221-22.

193. 677 F. App'x 884 (5th Cir. 2017).

194. Id at 889 .

195. Id.

196. Id

197. On how "junk science" improperly influences how a criminal defendant is treated in the judicial system, see Michael L. Perlin \& Alison J. Lynch, "Mr. Bad Example": Why Lawyers Need to Embrace Therapeutic Jurisprudence to Root out Sanism in the Representation of Persons with Mental Disabilities, 16 WYo. L. REV. 299, 312 (2016); Michael L. Perlin, "Deceived Me into Thinking/I Had Something to Protect": A Therapeutic Jurisprudence Analysis of When Multiple Experts Are Necessary in Cases in which Fact-Finders Rely on Heuristic Reasoning and "Ordinary Common Sense", 13 LAW J. SOG. JUST. 88, 118-19 (2020) [hereinafter Perlin, Deceived Me].

198. "Ordinary common sense" is "a powerful unconscious animator of legal decision making that reflects "idiosyncratic, reactive decisionmaking," and "is a psychological construct that reflects the level of the disparity between perception and reality that regularly pervades the judiciary in deciding cases involving individuals with mental disabilities." Perlin, Harmon \& Chatt, supra note 7, at 281, citing, inter alia, Michael L. Perlin, Psychodynamics and the Insanity Defense: "Ordinary Common Sense" and Heuristic Reasoning, 69 Neb. L. REv. 3, 22-23, 29 (1990) [hereinafter Perlin, Psychodynamics], and Richard K. Sherwin, Dialects and Dominance: A Study of Rhetorical Fields in the Law of Confessions, 136 U. PA. L. REV. 729, 737-38 (1988).

199. See, e.g., Mossman, supra note 148, at 276-77. One of the authors (Michael L. Perlin) wrote this just months after the decision in Atkins:
}

Dr. Dorothy Lewis documented that juveniles imprisoned on death row were quick to tell her and her associates, "I'm not crazy," or "I'm not a retard." Moreover, a person with mental retardation will often attempt to conceal his condition from lawyers, not realizing that his condition could 
rejection of the validity of the WISC test, ${ }^{200}$ its reliance on so-called ethnic adjustments, ${ }^{201}$ its failure to understand how most of us misunderstand expressions of remorse, ${ }^{202}$ and, as discussed extensively in our previous article, its failures to implement Strickland v. Washington in cases involving defendants with mental disabilities. ${ }^{203}$

\section{i. Failure to Rebut Malingering}

As we have already noted, if defense counsel did not rebut allegations of malingering, Atkins claims were practically universally unsuccessful. ${ }^{204}$ Thus, in Simpson v. Quarterman, ${ }^{205}$ the Court concluded that Simpson "had a very strong incentive to malinger in light of Atkins and Briseno when being tested by [the examining psychologists] in 2008," some eight years after his conviction and death sentence. ${ }^{206}$ Interestingly, the Court noted that the state's expert "admitted he has tested many defendants for the State of Texas, but

constitute a major part of his defense. Especially in a case in which counsel is substandard, this could-again-be fatal to a defendant who ought otherwise come under the Atkins umbrella.

Perlin, Life Is in Mirrors, supra note 18, at 342 (citing Joseph A. Nese, Jr., The Fate of Mentally Retarded Criminals: An Examination of the Propriety of Their Execution Under the Eighth Amendment, 40 Dud. L. Rev. 373, 383 (2002) and Rosa Ehrenreich \& Jamie Fellner, Beyond REASON: The DEATH PENalty and OfFenders With Mental Retardation 4 (Malcolm Smart \& Cynthia Brown eds., Hum. Rts. Watch) (2001)).

200. See infra Section III.D.ii.

201. On how such reliance reflects a corruption of the criminal justice system, see Perlin, Corrupt Ways, supra note 13.

202. See infra Section III.D.iv.

203. See Perlin, Harmon \& Chatt, supra note 7.

204. See, e.g., Ibarra v. Davis, 786 F. App'x 420 (5th Cir. 2019); Rockwell v. Davis, 853 F.3d 758 (5th Cir. 2017); Ladd v. Livingston, 777 F.3d 286 (5th Cir. 2015); Ladd v. Stephens, 748 F.3d 637 (5th Cir. 2014); Simpson v. Quarterman, 341 F. App'x 68 (5th Cir. 2009), dismissing appeal from 593 F. Supp. $2 d 922$ (E.D. Tex. 2009); Perkins v. Quarterman, 254 F. App'x 366 (5th Cir. 2007); Taylor v. Quarterman, 498 F.3d 306 (5th Cir. 2007); Clark v. Quarterman, 457 F.3d 441 (5th Cir. 2006); Moreno v. Dretke, 450 F.3d 158 (5th Cir. 2006). For subsequent developments on other grounds, see In re Taylor, 298 F. App'x 385 (5th Cir. 2008); Williams v. Stephens, 761 F.3d 561 (5th Cir. 2014). Although no version of the root word "malinger" appears in the litigation in Woods v. Quarterman, 493 F.3d 580, 586 (5th Cir. 2007), the court there concluded that "Woods' lowest IQ score was attained when he had an incentive to perform poorly, but Woods' IQ scores were higher when he had no such incentive" (emphasis added).

205. 341 F. App'x 68 (5th Cir. 2009), cert. denied, 558 U.S. 1039 (2009).

206. 593 F. Supp. 2d 922, 936 (E.D. Tex. 2009), appeal dismissed, 341 F. App'x 68 (5th Cir. 2009), cert. denied, 558 U.S. 1039 (2009). 
could not name one he found not to be malingering." 207 It does not appear that this issue was ever dealt with by trial counsel.

In Ladd v. Stephens, ${ }^{208}$ the Court found that the defendant was properly denied habeas relief, notwithstanding the testimony of his expert witness that he had "significantly sub-average intellectual functioning," ${ }^{209}$ accepting a state expert's opinion that the defendant "had a propensity for 'prevarication' and low motivation," and that defendant's subsequent IQ score of sixty was "unreliable because of malingering." ${ }^{210}$ And, in Woods v. Quarterman, ${ }^{211}$ a case in which the defendant's IQ scores fluctuated from sixty-eight to eighty-six, ${ }^{212}$ in finding that the state court's decision that Woods "failed to demonstrate that he suffered from subaverage general intellectual functioning was not unreasonable," ${ }^{13}$ the court concluded that "Woods' IQ scores were higher when he had no ... incentive to perform poorly," suggesting that he was malingering. ${ }^{214}$ No effort from the defense to refute this suggestion was mentioned in the opinion. ${ }^{215}$

\section{ii. Use of WISC Test}

Also, in those cases in which the defendant relied upon the WISC IQ test, his efforts on appeal were uniformly thwarted. Thus, in Taylor v. Quarterman, ${ }^{216}$ the doctor who administered the WISC test when Taylor was a child (ten years old) had stated that Taylor "was capable of performing better than a 75, had he tried." 117 Also, a WAIS-III score of sixty-five was discounted by the state habeas

207. Simpson, F. Supp. 2d at 937.

208. Ladd v. Stephens, 748 F. 3d 637 (5th Cir. 2014), cert. denied, 574 U.S. 880 (2014). For later proceedings, see Ladd v. Livingston, 777 F.3d 286 (5th Cir. 2015), cert. denied, 135 S. Ct. 1197 (2015).

209. Ladd, 748 F. 3d at 641. This conclusion was based on an IQ score of 67 that Ladd received at age 13, as well as an opinion from the Texas Youth Commissions psychiatrist that "Ladd appeared mentally retarded." $I d$.

210. Id at 643 .

211. Woods v. Quarterman, 493 F.3d 580 (5th Cir. 2007). For subsequent proceedings, see In re Woods, 296 S.W.3d 587 (Tex. Ct. Crim. App. 2009), cert. denied, 558 U.S. 1073 (2009).

212. Woods, 493 F.3d at 585-86.

213. Id. at 586 .

214. Id

215. Litigation is continuing in Long v. Davis, 706 F.App'x 181 (5th Cir. 2017). See Appendix $\mathrm{C}$.

216. Taylor v. Quarterman, 498 F.3d 306 (5th Cir. 2007).

217. Id. at 307. 
court "due to the incentive to malinger." 218 Similarly, in In re Mathis, ${ }^{219}$ although the defendant had been scored at sixty-four and sixty-two in WAIS tests, his WISC score of seventy-nine led-in part—to the Court rejecting his claims. ${ }^{220}$ And, in Simpson v. Quarterman, ${ }^{221}$ where the defendant had received scores of seventy-one on the WISC test (in sixth grade) and seventy-eight (at age fifteen), the fact that he achieved a full-scale score of seventy-one on the WAIS-III in 2000, resulted in part in the rejection of Simpson's claims. ${ }^{222}$

\section{iii. Use of "Ethnic Adjustments"}

Some prosecution experts have endorsed the use of what have been characterized as "ethnic adjustments" in death penalty cases-artificially adding points to the IQ scores of minority death penalty defendants - so as to make such defendants, who would otherwise have been protected by Atkins and, later, by Hall v. Florida, eligible for the death penalty. ${ }^{223}$ In his comprehensive discussion of this issue, Professor Robert Sanger accurately concluded that "ethnic adjustments" are not appropriate, clinically or logically, when calculating a defendant's IQ score for Atkins purposes." ${ }^{224}$ Further, he relied on epigenetics to demonstrate that environmental factors, such as childhood abuse, poverty, stress, and trauma, can result in lower IQ scores, and that "ethnic adjustments" make it more likely that such individuals—authentically "intellectually disabled"—will be sentenced and put to death. ${ }^{225}$ bring the phenotype into being." See CONRAD H. WADDINGTON, The Basic Ideas of Biology, in THE ORIGIN OF LIFE 1, 9-10 (Conrad H. Waddington ed., 1968); see also Fabian, Thompson \& Lazarus, supra note 159, at 414 (noting that the steady increase of the general population's IQ scores over time could be attributed to cultural changes, improved nutrition, testing experience, changes in schooling and child-rearing practices, and improved technology). Some of the forensic psychologists who have employed such adjustments in their
} 
In three cases, the Fifth Circuit affirmed death sentences in cases in which the discredited "ethnic adjustment" theory was used. ${ }^{226}$ Thus, in Hernandez $v$. Stephens, ${ }^{227}$ the defendant's appeal was denied, “[a]lthough the inmate's IQ scores were generally within the range of mental retardation." 228 There, where defendant's IQ scores ranged from fifty-two to fifty-seven, to, on one occasion, eighty-seven, ${ }^{229}$ a state's witness resolved the ambiguities by giving defendant a score of seventy when "his results were scaled to Mexican norms." ${ }^{230}$ Significantly, the Circuit concluded that "IQ tests below may not be mentally retarded." ${ }^{231}$ Again, it emphasized that " $[w]$ hen scaled to Mexican norms, Hernandez scored exactly 70 on

testimony are named and criticized in Shapiro et al., supra note 13 (discussing ethical issues raised by such testimony). On how the use of such fraudulent testimony may rise to the level of prosecutorial misconduct, see Perlin, Corrupt Ways, supra note 13, at 1453 (quoting, in part, James K. McAfee \& Michele Gural, Individuals with Mental Retardation and the Criminal Justice System: The View from States' Attorneys General, 26 Mental Retardation 5, 5 (1988) ("There has never been any 'pushback' against the argument that prosecutors regularly minimize the existence of intellectual disability. Tellingly, a survey of state attorneys general revealed that the identification of persons with intellectual disability in the criminal justice system 'is neither systematic nor probable."').

226. Two cases involving Dr. Denkowski's testimony had different ultimate dispositions. In Pierce v. Thaler, 604 F. 3d 197, 212 (5th Cir. 2010), where the witness "opined that Pierce's IQ might actually be slightly higher than this score suggested because Pierce suffered from moderate anxiety and mild depression, which may have suppressed the score," the defendant was ultimately resentenced to life without parole. See Allan Turner, DA's Office Plans to Not Seek Execution of Man on Death Row Since 1978, CHRON (last updated Aug. 30, 2012, 3:00 AM), https://www.chron.com/news/houston-texas/article/DA-s-office-plans-tonot-seek-execution-of-man-on-3825169.php. In Butler v. Stephens, 625 F. App'x 641, 644 (5th Cir. 2015), where the district court had found Dr. Denkowski to be "credible," four years later, the District Attorney's office agreed to new IQ testing, and will agree to a resentencing if Butler's score is 75 or below. E-mail from Richard Burr, United States Senator for North Carolina, to author (June 8, 2020 1:19 PM) (on file with author). Dr. Denkowski was also a witness in Hall v. Quarterman, 534 F.3d 365, 371 n.27 (5th Cir. 2008), a case in which "the trial court relied [on Dr. Denkowski's affidavit] in finding that Hall was not mentally retarded, [an affidavit that] indicated incorrectly that Dr. Church's examination of Hall produced an IQ score of 72; the score was in fact a 67" (emphasis added).

227. Hernandez v. Stephens, 537 F. App'x 531, 539 (5th Cir. 2013) (per curiam).

228. Id .

229. Id. at 536 .

230. Id . In this case, it appears that a suggestion of malingering or at least intentional underperforming of the defendant was accused and may partially explain one witness's opinion that the defendant "was not mentally retarded," and that that the defendant's "motivational variables likely played a role in the below-average scores." Id. at 537 (witness did not interview defendant himself).

231. Id. at 539. Here, pointedly, the Gircuit relied on its prior opinion in Lewis $v$. Thaler, 701 F.3d 783, 792 (5th Cir. 2012) (quoting the since-discredited case of Briseno, 135 S.W.3d at 7 n.24). 
the one full-scale WAIS-III test." ${ }^{232}$ The district court further found evidence that "Hernandez's motivation to score lower could have been a factor in the test results." 233

In Maldonado v. Thaler, ${ }^{234}$ the state's expert, Dr. George Denkowski, was a clinical psychologist who had been severely criticized and discredited based on his methodology, testing protocols, and "evaluation and scoring of Maldonado's intellectual functioning." ${ }^{235}$ Although the circuit court conceded that the Texas Board of Psychological Examiners had found that "the adjustments [Dr. Denkowski used] were not scientifically valid," ${ }^{236}$ it nonetheless found that the defendant "cannot meet his burden of showing that the state court's finding that he is not mentally retarded was either an unreasonable application of Atkins or an unreasonable determination of the facts in light of the evidence presented in state court." 237

Although noting that the "upward adjustments that Dr. Denkowski made to Maldonado's WAIS-III score" were of greater concern" because they "did not result from any statistical formula or established methodology and [because] Dr. Denkowski lacked the cultural knowledge to properly and accurately adjust for the effects of Maldonado's impoverished upbringing in rural Mexico," 238 the court concluded that, even if "Dr. Denkowski's testimony is interpreter who was licensed in Spanish/English translation, but who did not have a background in psychology and had no previous experience translating a "psychological instrument before Maldonado's examination." Id at at 236-37.
}

238. Id. at 238. 
completely disregarded, with the remaining evidence, [defendant] could not meet his burden for obtaining federal habeas relief." ${ }^{239}$

Finally, in Rivera v. Quarterman, ${ }^{240}$ where the court ultimately found that the defendant was intellectually disabled, suffering from "significant sub-average intellectual functioning," 241 the state had argued for the use of ethnic adjustments, claiming that defendant's "verbal IQ score of 66 [was] unreliable and dragged down his overall result." 242

Here, the state also argued that the district court erred in rejecting four pre-Atkins IQ scores of seventy, eighty-five, ninety-two and eighty; these were rejected because "they were not from fullscale Wechsler tests." ${ }^{243}$ Because, in part, of expert testimony that "IQ tests given in the criminal justice system don't hold much weight because of the wide variation," ${ }^{244}$ the court ultimately found "no clear error in the district court's determination that Rivera has significantly sub-average intellectual functioning," 245 affirming the finding that "Rivera is mentally retarded." ${ }^{446}$

\section{iv. Alleged Lack of Remorse}

The Supreme Court is cognizant of how the assessment of remorse and compassion might be the dispositive factor to jurors in death penalty cases. ${ }^{247}$ Concurring in Riggins $v$. Nevada, in which the

239. Id. at 239. The defendant also argued unsuccessfully that Dr. Denkowski did not take the "Flynn Effect" into consideration. Id. at 238.

240. Rivera v. Quarterman, 505 F.3d 349 (5th Cir. 2007).

241. Id. at 361 .

242. Id.

243. Id. at 362 .

244. Id.

245. Id.

246. Rivera, 505 F.3d at 363 . In yet another case involving Dr. Denkowski's testimony, the defendant presented evidence that that witness had "entered into a settlement agreement with the Texas State Board of Examiners of Psychologists in which he agreed to "not accept any engagement to perform forensic psychological services in the evaluation of subjects for mental retardation or intellectual disability in criminal proceedings." Matamoros v. Stephens, 783 F.3d 212, 214 (5th Cir. 2015). However, the court concluded that, even after excluding Dr. Denkowski's testimony, the defendant had not shown "clearly and convincingly that the court of Criminal Appeal's decision that the defendant did not meet his burden of proof-was unreasonable." Id. at 220, 227.

247. See generally Michael L. Perlin \& Heather Ellis Cucolo, 'Something's Happening Here/But You Don't Know What It Is': How Jurors (Mis)Construe Autism in the Criminal Trial Process, U. PITT. L. REV. (forthcoming 2021) (draft available at https://papers.ssrn.com/sol3/papers.cfm?abstract_id=3664705) [hereinafter Perlin \& Cucolo, Something's Happening]. 
Supreme Court held that competent insanity-pleaders had a qualified right to refuse medication at trial, ${ }^{248}$ Justice Kennedy underscored that " $[\mathrm{a}]$ ssessments of character and remorse may carry great weight and, perhaps, be determinative of whether the offender lives or dies." ${ }^{249}$ In that case, Riggins had been medicated with 800 milligrams of the drug Mellaril, considered to be within the "toxic range"; $;{ }^{250}$ an expert in the case testified that that was sufficient dosage with which to "tranquilize an elephant." 251 Justice Kennedy relied on research by William Geimer and Jonathan Amsterdam, whose research demonstrated that assessment of remorse might be the dispositive factor to jurors in death penalty cases. ${ }^{252}$

Subsequently, in Atkins, it held that demeanor of such defendants may create an unwarranted impression of a lack of remorse for their crimes. ${ }^{253}$ This impression, of course, in the death penalty context, could "enhance the likelihood that the jury will impose the death penalty due to a belief that they pose a future danger." 254

In particular, judges must explain to jurors that they cannot rely on their false "ordinary common sense" 255 about what remorse "looks like" or what an empathetic person "looks like." 556 Again,

248. Riggins v. Nevada, 504 U.S. 127, 144 (1992) (Kennedy, J., concurring).

249. Id.

250. Id. at 137 .

251. Id. at 143 .

252. Id. at 143-44 (citing Geimer \& Amsterdam, supra note 30, at 51-52); see also Perlin, Merchants and Thieves, supra note 9, at 1531.

253. Atkins v. Virginia, 536 U.S. 304 at 320-21 (2004) (noting the difficulties persons with intellectual disabilities (then characterized as mental retardation) may have in being able to give meaningful assistance to their counsel as well as their status as "typically poor witnesses.").

254. See John H. Blume \& Sheri Lynn Johnson, Killing the Non-Willing: Atkins, the Volitionally Incapacitated, and the Death Penalty, 55 S.C. L. Rev. 93, 108 (2003).

255. See Perlin \& Cucolo, Something's Happening, supra note 247 (citing Perlin, Harmon \& Chatt, supra note 7 , at 281 (explaining the meaning of "ordinary common sense" in this context (citing Sherwin, supra note 198, at 737-38, and Perlin, Psychodynamics, supra note 198, at 29))). Ordinary common sense presupposes two "self-evident" truths: first, everyone knows how to assess an individual's behavior; and second, everyone knows when to blame someone for doing wrong. Michael L. Perlin, Myths, Realities, and the Political World: The Anthropology of Insanity Defense Attitudes, 24 BULL. AM. ACAD. PsyCHIATRY \& L. 5,17 (1996). It is self-referential and non-reflective; "I see it that way, therefore everyone sees it that way; I see it that way, therefore that's the way it is." Perlin, Dorfman \& Weinstein, supra note 141 , at 88.

256. This, of course, presupposes that judges do not fall prey to the same sort of false ordinary common sense. See, e.g., Colleen M. Berryessa, Judiciary Views on Criminal Behaviour and Intention of Offenders with High-Functioning Autism, 5 J. InTELl. DisAB. \& OFFENDing 
judges must make clear that jurors' "ordinary common sense" is simply wrong-that it is premised on media stereotypes or, perhaps, the heuristic of one person that they may know, and that it cannot be left unchecked or guide their decisions in reaching a verdict. ${ }^{257}$

In cases in which Atkins claims were rejected, in cases where they were successful, and in cases involving other mental disability issues beyond those related specifically to intellectual disability, the Fifth Circuit decisions reveal no reflection on the remorse-related issues just discussed..$^{258}$

\section{v. Issues Related to Effectiveness of Counsel}

In Strickland $v$. Washington, the Supreme Court had found that counsel would be ineffective if his or her "conduct so undermined the proper function of the adversarial process that the trial court cannot be relied on as having produced a just result." ${ }^{259}$ The Court established a two-part test to assess whether counsel's assistance was "so defective as to require reversal": ${ }^{260}$

First, the defendant must show that counsel's performance was deficient. This requires showing that counsel made errors so serious that counsel was not functioning as the "counsel" guaranteed the defendant by the Sixth Amendment. Second, the defendant must show that the

BEHAV. 97 (2014) (interviewed judges that believed persons with autism do not have control of their behavior).

257. See, e.g., Colleen Berryessa, Judicial Perceptions of Media Pontrayals of Offenders with High Functioning Autistic Spectrum Disorders, 3 INT'L J. CRIM. SOCIO. 46 (2014). On how ordinary common sense is supported by cognitive-simplifying heuristics, see Perlin \& Cucolo, Something's Happening, supra note 247 , at 453.

258. See, e.g., Mathis v. Dretke, No. 04-70015, 2005 U.S. App. LEXIS 4210, at *26 (5th Cir. Mar. 11, 2005) (including testimony from a jailhouse informant that "Mathis confessed to the killings and expressed no remorse") (finding that the Atkins claim failed); Williams v. Stephens, 761 F.3d 561, 568 (5th Cir. 2014) (including testimony from state experts as to defendant's "lack of remorse") (finding that the Atkins claim failed); Martinez v. Davis, No. 15-70017, 2016 U.S. App. LEXIS 11640, at*9 (5th Cir. June 24, 2016) (including testimony from family members that defendant "showed little remorse"), vacated 137 S. Ct. 1432 (2017); Sells v. Stephens, No. 12-70028, 2013 U.S. App. LEXIS 14799, at *5-6 (5th Cir. July 22, 2013) (including testimony from the state's witness that defendant "displayed no remorse"); Sigala v. Quarterman, No. 08-70013, 2009 U.S. App. LEXIS 16026, at*19 (5th Cir. July 20, 2009) (quoting Ex parte Sigala, No. 62,283-01, slip op. at 21 (Tex. Crim. App. Aug. 31, 2005)); Coble v. Quarterman, 496 F.3d 430, 438 (5th Cir. 2007) (detailing how immediately following the murders, "Coble made comments that indicated his lack of remorse").

259. Strickland v. Washington, 466 U.S. 668, 686 (1984).

260. Id. at 687 . 
deficient performance prejudiced the defense. This requires showing that counsel's errors were so serious as to deprive the defendant of a fair trial, a trial whose result is reliable. Unless a defendant makes both showings, it cannot be said that the conviction or death sentence resulted from a breakdown in the adversary process that renders the result unreliable. ${ }^{261}$

The "objective" of "reasonably effective assistance" standard was to be measured by "simply reasonableness under prevailing professional norms." ${ }^{262}$ As part of this measurement, the Court would "indulge a strong presumption that counsel's conduct falls within the wide range of reasonable professional assistance." ${ }^{263}$ We must keep this "pallid" standard ${ }^{264}$ in mind throughout this investigation. ${ }^{265}$

Thus, efforts by Atkins defendants to come under the umbrella of the standard of adequacy of counsel announced in Strickland were nearly uniformly unsuccessful. Of the twenty-two cases in

261. Id .

262. Id. at $687-88$.

263. Id. at 689 .

264. See, e.g., Michael L. Perlin, "And I See Through Your Brain": Access to Experts, Competency to Consent, and the Impact of Antipsychotic Medications in Neuroimaging Cases in the Criminal Trial Process, 2009 STAN. TEGH. L. REV. 4, *24 n.88 (2009).

265. See generally Perlin, Harmon \& Chatt, supra note 7, at 264 (explaining how "the charade of 'adequacy of counsel law' fails miserably" in the Fifth Circuit). 
which Strickland was raised, ${ }^{266}$ there was partial success in only three: Pierce v. Thaler, ${ }^{267}$ Butler v. Stephens, ${ }^{268}$ and Busby v. Davis. ${ }^{269}$

In Pierce, the Fifth Circuit initially ruled that the defendant was entitled to a certificate of appealability ("COA") on his ineffectiveness of counsel claim. ${ }^{270}$ Subsequently, however, the same court ruled that the defendant was not entitled to an evidentiary hearing in the federal district court on his claim under Atkins, that his intellectual disability estopped the state from executing him. ${ }^{271}$ Eventually, after thirty-five years on death row, the defendant was resentenced to life without parole. ${ }^{272}$ In Busby, the Fifth Circuit granted a COA on the questions of whether the defendant received ineffective assistance of direct appeal counsel, and whether trial counsel was ineffective by failing to conduct an adequate sentencing investigation or to present an adequate mitigation case during the

266. See Ibarra v. Davis, No. 17-70014, 2019 U.S. App. LEXIS 25535, at*6 (5th Cir. Aug. 26, 2019); Butler v. Stephens, No. 18-70006, 2018 U.S. App. LEXIS 22494, at*10 (5th Cir. Aug. 14, 2018); Guevara v. Davis, No. 16-70004, 2017 U.S. App. LEXIS 2374, at *1-2 (5th Cir. Feb. 9, 2017); Rockwell v. Davis, 853 F.3d 758, 761 (5th Cir. 2017); Shore v. Davis, 845 F.3d 627, 632 (5th Cir. 2017); Martinez v. Davis, No. 15-70017, 2016 U.S. App. LEXIS 11640 , at *9 (5th Cir. June 24, 2016); Segundo v. Davis, 831 F.3d 345, 350 (5th Cir. 2016); In re Chase, 804 F.3d 738, 738 (5th Cir. 2015); Guevara v. Stephens, No. 13-70003, 2014 U.S. App. LEXIS 15357, at *10 (5th Cir. Aug. 11, 2014); Mays v. Stephens, 757 F. 3d 211, 214 (5th Cir. 2014); Williams v. Stephens, 761 F.3d 561, 566 (5th Cir. 2014); Tamayo v. Stephens, 740 F.3d 986, 988 (5th Cir. 2014); United States v. Bourgeois, No. 11-70024, 2013 U.S. App. LEXIS 16168, at*39 (5th Cir. Aug. 5, 2013); Ripkowski v. Thaler, No. 10-70021, 2011 U.S. App. LEXIS 17346, at *21 (5th Cir. Aug. 17, 2011); Esparza v. Thaler, No. 1070009, 2010 U.S. App. LEXIS 23368, at*23 (5th Cir. Nov. 9, 2010); Pierce v. Thaler, No. 0870042, 2010 U.S. App. LEXIS 8031, at *2 (5th Cir. Apr. 19, 2010); Perkins v. Quarterman, No. 07-70010, 2007 U.S. App. LEXIS 26523, at*10 (5th Cir. Nov. 15, 2007); Mathis v. Dretke, No. 04-70015, 2005 U.S. App. LEXIS 4210, at*34 (5th Cir. Mar. 11, 2005); United States v. Webster, 392 F.3d 787, 793 (5th Cir. 2004); Ladd v. Cockrell, 311 F.3d 349, 357 (5th Cir. 2002); Smith v. Cockrell, 311 F.3d 661, 668 (5th Cir. 2002), abrogated by Tennard v. Dretke, 542 U.S. 274 (2004); Thomas v. Cockrell, No. 01-11475, 2002 WL 31730148, at*4 (5th Cir. Nov. 18, 2002) (rejecting Thomas's argument that his "counsel was ineffective for failing to place Thomas's mental condition in issue during the guilt/innocence phase of trial").

267. Pierce v. Thaler, 355 F. App'x 784 (5th Cir. 2009), remanded to 604 F3d 197 (5th Cir. 2010). Pierce is discussed in Perlin, Harmon \& Chatt, supra note 7, at 333.

268. Butler v. Stephens, 625 F. App'x 641 (5th Cir. 2015).

269. Busby v. Davis, 925 F3d 699 (5th Cir. 2019), cert. denied, 140 S. Ct. 897 (2020).

270. Pierce, 355 F. App'x at 796-97. Pierce's trial lawyer was subsequently suspended. See In re Ronald G. Mock, Bd. Disciplinary App., Tex. (Dec. 8, 2004), http://txboda.org/ cases/re-ronald-g-mock.

271. Pierce v. Thaler, 604 F.3d 197 (5th Cir. 2010).

272. See Allan Turner, DA's Office Plans to Not Seek Execution of Man on Death Row Since 1978, CHRON (Aug. 30, 2012, 3:00 AM), https://www.chron.com/news/houston-texas/article/DA-s-office-plans-to-not-seek-execution-of-man-on-3825169.php. 
penalty phase of trial. ${ }^{273}$ On rehearing, the Fifth Circuit held that Busby did not establish ineffectiveness by counsel, and again affirmed the conviction, concluding that the defendant was not prejudiced by trial counsel's allegedly deficient mitigation investigation. ${ }^{274}$

In Buller, the court granted a COA on the ineffective assistance of trial counsel in failing to investigate and raise Butler's mental state regarding his competence to stand trial and as mitigation evidence during sentencing, ${ }^{275}$ and, in a subsequent opinion, vacated the dismissal of his ineffective-assistance-of-trial-counsel claim, remanding for further consideration. ${ }^{276}$ Then, in a later case on remand to the district court, his claims were ultimately rejected. ${ }^{277}$

In short, the conclusion reached by one of the co-authors some seven years ago- "Atkins [has] failed to prevent the execution of persons with serious mental disabilities"278-is still a valid one.

\section{E. Therapeutic Jurisprudence $\mathcal{E}$ Other Jurisprudential Filters}

\section{i. Therapeutic Jurisprudence Generally ${ }^{279}$}

Therapeutic jurisprudence ("TJ") recognizes that, as a therapeutic agent, the law can have therapeutic or anti-therapeutic consequences. ${ }^{280}$ It asks whether legal rules, procedures, and lawyer roles can or should be reshaped to enhance their therapeutic potential while not subordinating due process principles. ${ }^{281}$ Professor

\footnotetext{
273. 677 F. App'x 884, 889 (5th Cir. 2017).

274. 925 F.3d 699, 726 (5th Cir. 2019).

275. 600 F. App'x 246, 247 (5th Cir. 2015).

276. 625 F. App'x 641, 660 (5th Cir. 2015).

277. 745 F. App'x 528, 529 (5th Cir. 2018). Busby is discussed in Perlin, Harmon \& Chatt, supra note 7 , at 299-300.

278. Michael L. Perlin, Mental Disability and the Death Penalty: The Shame of the States 153 (2013) [hereinafter Perlin, Shame of the States]. 08.

279. This section is largely adapted from Perlin, Harmon \& Chatt, supra note 7, at 305-

280. It also distills the work of one of the authors over the past twenty-eight years, beginning with Michael L. Perlin, What Is Therapeutic Jurisprudence?, 10 N.Y.L. SCH. J. HUM. RTS. 623 (1993).

281. Michael L. Perlin, "And My Best Friend, My Doctor/Won't Even Say What It Is I've Got": The Role and Significance of Counsel in Right to Refuse Treatment Cases, 42 SAN DIEGO L. REV. $735,751(2005)$.
} 
David Wexler clearly identifies how the inherent tension in this inquiry must be resolved: " $[\mathrm{t}]$ he key task is . . to determine how the law can use mental health information to improve therapeutic functioning without impinging upon justice concerns." ${ }^{282}$ As one of the authors (Michael L. Perlin) has written elsewhere, "[a]n inquiry into therapeutic outcomes does not mean that therapeutic concerns 'trump' civil rights and civil liberties." 283 Therapeutic jurisprudence "look[s] at law as it actually impacts people's lives," ports "an ethic of care." 285 It emphasizes psychological wellness over adversarial triumphalism." "286 As noted in Therapeutic Jurisprudence and the Civil Rights of Institutionalized Mentally Disabled Persons: Hopeless Oxymoron or Path to Redemption?, "The perception of receiving a fair hearing is therapeutic because it contributes to the individual's sense of dignity and conveys that he or she is being taken seriously." "287

Professor Amy Ronner describes the "three Vs" as: ${ }^{288}$

$>$ Voice: litigants must have a sense of voice or a chance to tell their story to a decisionmaker; ${ }^{289}$

$>$ Validation: the decision maker needs to take seriously the litigant's story; ${ }^{290}$ and

282. David B. Wexler, Therapeutic Jurisprudence and Changing Concepts of Legal Scholarship, 11 BEHAV. SCI. \& L. 17, 21 (1993).

283. Michael L. Perlin, A Law of Healing, 68 U. CIN. L. REV. 407, 412 (2000).

284. Bruce J. Winick, Foreword: Therapeutic Jurisprudence Perspectives on Dealing with Victims of Crime, 33 Nova L. Rev. 535, 535 (2009).

285. Michael L. Perlin, "I've Got My Mind Made Up": How Judicial Teleology in Cases Involving Biologically Based Evidence Violates Therapeutic Jurisprudence, 24 CARD. J. EQUAL RTS. \& SOG. JUST. 81, 94 (2018) (quoting, in part, Bruce J. Winick \& David B. Wexler, The Use of Therapeutic Jurisprudence in Law School Clinical Education: Transforming the Criminal Law Clinic, 13 CLINICAL L. Rev. 605, 605-07 (2006)) [hereinafter Perlin, Mind Made Up].

286. Warren Brookbanks, Therapeutic Jurisprudence: Conceiving an Ethical Framework, 8 J.L. \& MED. 328, 329-30 (2001).

287. Michael L. Perlin, Keri K. Gould \& Deborah A. Dorfman, Therapeutic Jurisprudence and the Civil Rights of Institutionalized Mentally Disabled Persons: Hopeless Oxymoron or Path to Redemption?, 1 PsYCH. PUB. POL'Y \& L. 80, 114 (1995).

288. See, e.g., Amy D. Ronner, The Learned-Helpless Lawyer: Clinical Legal Education and Therapeutic Jurisprudence as Antidotes to Bartleby Syndrome, 24 TOURO L. REV. 601, 627 (2008).

289. On the importance of "voice," see Ian Freckelton, Therapeutic Jurisprudence Misunderstood and Misrepresented: The Price and Risks of Influence, 30 T. JEFFERSON L. REV. 575, 588 (2008).

290. Ronner, supra note 288, at 628. 
Voluntariness: in general, human beings prosper when they feel that they are making, or at least participating in, their own decisions. ${ }^{291}$

In discussing these " 3 V's," Professor Ronner underscores: "In general, human beings prosper when they feel that they are making, or at least participating in, their own decisions." ${ }^{292}$ The question we need to consider here is the extent to which the Fifth Circuit's post-Atkins decisions that are discussed in this paper comport with therapeutic jurisprudence principles.

\section{ii. TJ and the Cases Before Us}

There is very little in the TJ literature about these issues. In an earlier paper, one of the authors (Michael L. Perlin) has asked whether we can "remotely speak of voice, validation, or voluntariness in the context of cases in which persons with intellectual disability inappropriately face the death penalty based on fraudulent testimony premised on spurious "ethnic adjustments"??293 Elsewhere, in an article with other colleagues, the same co-author noted that "psychological testing and a comprehensive review of relevant contributing developmental factors can yield critical information that can provide mitigation and potential solutions consistent with the goals of therapeutic jurisprudence." 294 In an article with other colleagues, the same co-author has noted-speaking specifically of issues related to malingering-how "social science that enables judges to satisfy predetermined positions is privileged." ${ }^{295}$ David Wexler has wisely suggested that, in some cases, an expert witness might be called "to counter any claim of malingering." ${ }^{996}$ And Monica Miller and her colleagues have argued that "expressions of remorse are central to the idea of . . . therapeutic jurisprudence." 297

291. Amy D. Ronner, Songs of Validation, Voice, and Voluntary Participation: Therapeutic Jurisprudence, Miranda and Juveniles, 71 U. CIN. L. REV. 89, 95 (2002).

292. Id.

293. Perlin, Corrupt Ways, supra note 13, at 1457.

294. Michael L. Perlin, Alison J. Lynch \& Valerie R. McClain, "Some Things are Too Hot to Touch": Competency, the Right to Sexual Autonomy, and the Roles of Lawyers and Expert Witnesses, 35 TOuro L. REV. 405, 422 (2019).

295. Perlin, Dorfman \& Weinstein, supra note 141 , at 94 n.222.

296. David B. Wexler, Therapeutic Jurisprudence and the Rehabilitative Role of the Criminal Defense Lawyer, 17 ST. ThOMAS L. REV. 743, 755 n.60 (2005).

297. Monica K. Miller et al., How Emotion Affects the Trial Process, 92 JUDICATURE 56, 61 (2008). But see Perlin, Sanist Lives, supra note 8, at 279 (" $[\mathrm{I}] \mathrm{f}$ jurors continue to 'translate' a defendant's medicated state into evidence of non-remorse (thus enhancing the chances 
But otherwise, there is virtually nothing in the TJ literature on this topic.

In writing about the Fifth Circuit's Strickland decisions in cases involving mentally disabled defendants facing the death penalty, two of the authors of this article (Michael L. Perlin \& Talia Roitberg Harmon) concluded on this point:

It is fatuous to even consider whether the therapeutic principles to which the creators of TJ have aspired are part of either the trials of the defendants in this cohort of cases or the actions by counsel. Certainly, "socio-psychological insights into the law and its application" 298 are utterly lacking, as is any shred of evidence of a commitment to dignity. The caselaw is totally bereft of . . . TJrequired fair process norms. . . ${ }^{299}$

The countenancing of the use of ethnic adjustments, the tiresome and threadbare allegations of malingering, ${ }^{300}$ the sanist demands that remorse be exhibited in a way that comports with factfinders' false "ordinary common sense," the failure to employ accurate science in considering the potential impact of the Flynn Effect or the type of IQ test used all basely, and disgracefully, violate the most minimal standards of therapeutic jurisprudence, and ignore any notion of "dignity." As the Circuit's interpretation of the Strickland standard "failed miserably as an aspirational bulwark" of due process, ${ }^{301}$ so has the Circuit similarly failed miserably in its inability to bring "socio-psychological insights into [this area of] the law and its application." ${ }^{302}$ Do court procedures remotely "ensure that the defendant has a "voice?", ${ }^{303}$ Are defense expert witnesses able to

that a death penalty will be meted out), what impact should this have on the right of criminal defendants to refuse such treatment?").

298. Freckelton, supra note 289 , at 576.

299. Perlin, Harmon \& Chatt, supra note 7, at 307.

300. See Fellner, supra note 223, at 12-13 (discussing the role of prosecution experts in this context and explaining how prosecutors regularly "vigorously challenge the existence of mental retardation [and] minimize its significance....").

301. Perlin, Harmon \& Chatt, supra note 7, at 304.

302. Freckelton, supra note 289, at 576; see also Perlin, Mind Made Up, supra note 285, at 81 ("Courts are, and have always been, teleological in cases involving litigants with mental disabilities. By 'teleological,' I refer to outcome-determinative reasoning; social science that enables judges to satisfy predetermined positions is privileged, while data that would require judges to question such ends are rejected.").

303. Perlin, Shame of the States, supra note 278 , at 67. 
"disentangle meanings of reports, to contextualize IQ scores, to explain acts that might seem to be otherwise inexplicable and contrary to jurors' "ordinary common sense?" ${ }^{304}$ In the vast majority of cases, fair process norms are totally absent. ${ }^{305}$

\section{CONCLUSION}

The database we have considered here is infinitely depressing. There was only actual relief in $12.4 \%$ of the cases that raised Atkins issues, and this grouping of nine cases includes two in which the defendant died before the final relief could be implemented. What it reveals is a Court with little or no interest in the thoughtful opinions of Justice Stevens in Atkins and of Justice Kennedy in Hall. The science and jurisprudence are ignored. Baseless fears of undetected malingering, the mindless use of lay stereotypes of what "looks like" remorse, and the corrupt employment of "ethnic adjustments" to lawlessly raise IQ scores making certain minority defendants improperly eligible for execution all are reflected in the cases decided by the Fifth Circuit. Certainly, the earlier conclusion reached by Professor John Blume and his colleagues (in their empirical study of all Atkins claims) - that "Atkins is not evenhandedly protecting those it was designed to protect" 306 _rings as true today as it did when written eleven years ago.

On the other hand, the cases reveal important potential strategies for defense counsel: (1) It is essential that allegations of malingering be vigorously rebutted through expert testimony; (2) even though the Fifth Circuit has not yet acknowledged its scientific validity, the Flynn effect must be brought to the Court's attention, (3) the defendant should be given a WAIS test, and the WISC test must be avoided, (4) the use of lay stereotypes of "showing remorse" must be firmly discredited. If these are all done, then there is at least some chance that Atkins and its progeny will be given life in subsequent cases.

As we noted earlier, the song, License to Kill, upon which we have drawn in part for our title, is about corruption and "the havoc man wreaks upon himself." ${ }^{307}$ In another lyric in the song, Dylan

304. Id. See Perlin, Deceived Me, supra note 197, at 118-19 (discussing on the potential need for multiple experts in such cases).

305. Perlin, Harmon \& Chatt, supra note 7, at 307.

306. Blume et al., An Empirical Look, supra note 36, at 639.

307. Bob DyLAN, License to Kill, on INFIDELs (Columbia Records 1983). 
sings, "Man has invented his doom." 308 In cases in which no expert was offered to rebut allegations of malingering, or in which the "wrong" IQ test was relied upon, counsel has "invented ... doom" for the client. ${ }^{309}$ And sadly, there is no conclusion for us to reach other than the Fifth Circuit-through its meretricious decisionmaking-has bestowed on state departments of corrections a license to kill.

Seven years ago, one of the co-authors of this article (Michael L. Perlin) wrote a book he titled Mental Disability AND THE Death Penalty: The Shame of the States. ${ }^{310}$ An alternative title for this article could have been Mental Disability and the Death Penalty: The Shame of the Fifth Circuit.

308. Id

309. See Perlin, Harmon \& Chatt, supra note 7 (discussing the Fifth Circuit and adequacy of counsel generally).

310. See Perlin, Shame of the States, supra note 278, at 153. 
APPENDIX A: CODING SHEET

Successful Atkins Claim? (Y/N)

Numerical IQ Score? (Y/N and actual IQ score number ([if provided])

Not English Speaking? (Y/N)

"Borderline" ID Case? (Y/N)

Retroactive application? $(\mathrm{Y} / \mathrm{N})$

Costs to identify $\mathrm{ID}$ ? $(\mathrm{Y} / \mathrm{N}$; and what costs are)

Lack of Remorse? (Y/N)

Strickland Claim? (Y/N)

ID used as an aggravation? $(\mathrm{Y} / \mathrm{N})$

Ake Claims? (Y/N)

Experts in case? (Y/N)

Expert who Explained IQ? $(\mathrm{Y} / \mathrm{N})$

Did expert use/argue ethnic adjustments? (Y/N)

Did expert use/argue Flynn Effect? (Y/N)

Fake Claims mentioned? (Y/N)

Mental illness? (Y/N)

Expanding Atkins? (Y/N)

Use Briseno? $(\mathrm{Y} / \mathrm{N})$

Mention Hall? $(\mathrm{Y} / \mathrm{N})$

Mention Moore? (Y/N) 
APPENDIX B: LIST OF DEFENDANTS

\begin{tabular}{|c|c|c|}
\hline Defendant Name & Cases in the Fifth Circuit COA & Success? \\
\hline Bell, Walter, Jr. & $\begin{array}{l}\text { Bell v. Cockrell, } 310 \text { F. } 3 \text { d } 330 \\
\text { (5th Cir. 2002). }\end{array}$ & $\begin{array}{l}\text { Yes (SCR) } \\
\text { Success- } \\
\text { life }\end{array}$ \\
\hline Blue, Carl Henry & $\begin{array}{l}\text { Blue v. Thaler, } 665 \text { F. 3d } 647 \\
\text { (5th Cir. 2011), cert. denied, } 568 \\
\text { U.S. } 828 \text { (2012), supplemented } \\
\text { on other grounds, sub. nom., Blue } \\
\text { v. Thaler (In re Blue), 514 F. } \\
\text { App'x } 441 \text { (5th Cir. 2013). }\end{array}$ & $\begin{array}{l}\text { No } \\
\text { Failure }\end{array}$ \\
\hline $\begin{array}{l}\text { Bourgeois, } \\
\text { Alfred }\end{array}$ & $\begin{array}{l}\text { United States v. Bourgeois, } 537 \\
\text { F. App'x } 604 \text { (5th Cir. } \\
\text { 2013), cert. denied, } 574 \text { U.S. } 827 \\
\text { (2014), supplemented on other } \\
\text { grounds, sub.. nom., In re } \\
\text { Bourgeois, } 902 \text { F. } 3 d 446 \\
\text { (5th Cir. } 2018 \text { ). }\end{array}$ & $\begin{array}{l}\text { No } \\
\text { Failure }\end{array}$ \\
\hline $\begin{array}{l}\text { Brown, Mauriceo } \\
\text { Mashawn }\end{array}$ & $\begin{array}{l}\text { In re Brown, } 457 \text { F. 3d } 392 \text { (5th } \\
\text { Cir. 2006). }\end{array}$ & $\begin{array}{l}\text { No } \\
\text { Failure }\end{array}$ \\
\hline $\begin{array}{l}\text { Brumfield, } \\
\text { Kevan }\end{array}$ & $\begin{array}{l}\text { Brumfield v. Cain, } 740 \text { F. 3d } \\
946 \text { (5th Cir. 2014), cert den., } \\
576 \text { U.S. } 305 \text { (2015). For earlier } \\
\text { litigation in the Brumfield case, } \\
\text { see, e.g., Brumfield v. Cain, } 808 \\
\text { F. 3d 1041 (5th Cir. 2015) and } \\
\text { Brumfield v. Cain, } 744 \text { F. 3d } \\
918 \text { (5th Cir. 2014). }\end{array}$ & $\begin{array}{l}\text { Yes } \\
\text { Success- } \\
\text { life }\end{array}$ \\
\hline $\begin{array}{l}\text { Busby, Edward } \\
\text { Lee }\end{array}$ & $\begin{array}{l}\text { Busby v. Davis, } 925 \text { F. 3d } 699 \\
\text { (5th Cir. 2019), cert den., } 140 \text { S. } \\
\text { Ct. } 897 \text { (2020). For earlier } \\
\text { litigation in the Busby case, see, } \\
\text { e.g., Busby v. Davis, } 892 \text { F. 3d } \\
735 \text { (5th Cir. 2018) and Busby } \\
\text { v. Davis, 677 F. App'x } 884 \text { (5th } \\
\text { Cir. 2017). }\end{array}$ & $\begin{array}{l}\text { Partial } \\
\text { Partial } \\
\text { turn fail-to } \\
\text { be } \\
\text { executed }\end{array}$ \\
\hline
\end{tabular}




\begin{tabular}{|c|c|c|}
\hline $\begin{array}{l}\text { Butler, Steven } \\
\text { Anthony }\end{array}$ & $\begin{array}{l}\text { Butler v. Stephens, } 625 \text { F. } \\
\text { App'x } 641 \text { (5th Cir. 2015), cert } \\
\text { den., } 136 \text { S. Ct. } 1656 \text { (2016). } \\
\text { For earlier litigation in the } \\
\text { Butler case, see, e.g., Butler v. } \\
\text { Stephens, 600 F. App'x } 246 \\
\text { (5th Cir. 2015). }\end{array}$ & $\begin{array}{l}\text { Maybe a } \\
\text { success }\end{array}$ \\
\hline $\begin{array}{l}\text { Campbell, } \\
\text { Robert James }\end{array}$ & $\begin{array}{l}\text { In re Campbell, } 750 \text { F. 3d } 523 \\
\text { (5th Cir. 2014) For earlier } \\
\text { litigation in the Campbell case, } \\
\text { see, e.g., Campbell v. Dretke, } \\
117 \text { F. App'x } 946 \text { ( } 5 \text { th Cir. } \\
\text { 2004), cert den., } 546 \text { U.S. } 1015 \\
\text { (2005) and In re Campbell, } 82 \\
\text { F. App'x } 349,350 \text { (5th Cir. } \\
\text { 2003). }\end{array}$ & $\begin{array}{l}\text { Yes } \\
\text { Success- } \\
\text { life- } \\
\text { eligible for } \\
\text { parole }\end{array}$ \\
\hline $\begin{array}{l}\text { Cathey, Eric } \\
\text { Dewayne }\end{array}$ & $\begin{array}{l}\text { Cathey v. Davis (In re Cathey), } \\
857 \text { F. 3d } 221 \text { (5th Cir. 2017). }\end{array}$ & $\begin{array}{l}\text { Yes } \\
\text { Maybe a } \\
\text { success }\end{array}$ \\
\hline Chase, Ricky R & $\begin{array}{l}\text { In re Chase, } 804 \text { F. 3d } 738 \text { (5th } \\
\text { Cir. 2015). }\end{array}$ & $\begin{array}{l}\text { Yes } \\
\text { Maybe a } \\
\text { success }\end{array}$ \\
\hline Chester, Elroy & $\begin{array}{l}\text { Chester v. Thaler, } 666 \text { F. 3d } 340 \\
\text { (5th Cir. 2011), cert den., } 568 \\
\text { U.S. } 978 \text { (2012), supplemented } \\
\text { on other grounds, sub.. nom., } \\
\text { Chester v. Thaler, } 671 \text { F. 3d } 494 \\
\text { (5th Cir. 2012). For earlier } \\
\text { litigation in the Chester case, } \\
\text { see, e.g., Chester v. Cockrell, } 62 \\
\text { F. App'x } 556 \text { (5th Cir. 2003). }\end{array}$ & $\begin{array}{l}\text { No } \\
\text { Failure }\end{array}$ \\
\hline Clark, James Lee & $\begin{array}{l}\text { Clark v. Quarterman, } 457 \text { F. 3d } \\
441 \text { (5th Cir. 2006), cert den., } \\
549 \text { U.S. } 1254(2007) .\end{array}$ & $\begin{array}{l}\text { No } \\
\text { Failure }\end{array}$ \\
\hline
\end{tabular}




\begin{tabular}{|c|c|c|}
\hline $\begin{array}{l}\text { Eldridge, Gerald } \\
\text { Cornelius }\end{array}$ & $\begin{array}{l}\text { Eldridge v. Davis, 661 F. App'x } \\
253 \text { (5th Cir. 2016), cert den., } \\
137 \text { S. Ct. } 2215 \text { (2017). For } \\
\text { earlier litigation in the Eldridge } \\
\text { case, see, e.g., Eldridge v. } \\
\text { Stephens, 599 F. App'x } 123 \\
\text { (5th Cir. } 2015 \text { ); Eldridge v. } \\
\text { Stephens } 608 \text { F. App'x } 289 \text { (5th } \\
\text { Cir. 2015); and Eldridge v. } \\
\text { Quarterman, } 325 \text { F. App'x } 322 \\
\text { (5th Cir. 2009). }\end{array}$ & $\begin{array}{l}\text { No } \\
\text { Failure }\end{array}$ \\
\hline $\begin{array}{l}\text { Esparza, } \\
\text { Guadalupe }\end{array}$ & $\begin{array}{l}\text { Esparza v. Thaler, } 408 \text { F. App'x } \\
787 \text { (5th Cir. 2010), cert den., } \\
563 \text { U.S. } 992(2011) .\end{array}$ & $\begin{array}{l}\text { No } \\
\text { Failure }\end{array}$ \\
\hline $\begin{array}{l}\text { Garcia, Juan } \\
\text { Martin }\end{array}$ & $\begin{array}{l}\text { Garcia v. Stephens, } 757 \text { F. 3d } \\
220 \text { (5th Cir. 2014), cert den., } \\
574 \text { U.S. } 1193(2015) .\end{array}$ & $\begin{array}{l}\text { No } \\
\text { Failure }\end{array}$ \\
\hline $\begin{array}{l}\text { Guevara, Gilmar } \\
\text { Alexander }\end{array}$ & $\begin{array}{l}\text { Guevara v. Davis, } 679 \text { F. App'x } \\
332 \text { (5th Cir. 2017), cert den., } \\
138 \text { S. Ct. } 554 \text { (2015). For } \\
\text { earlier litigation in the Guevara } \\
\text { case, see, e.g., Guevara v. } \\
\text { Stephens, } 577 \text { F. App'x } 364 \\
\text { (5th Cir. 2014). }\end{array}$ & $\begin{array}{l}\text { No } \\
\text { failure }\end{array}$ \\
\hline $\begin{array}{l}\text { Hall, Michael } \\
\text { Wayne }\end{array}$ & $\begin{array}{l}\text { Hall v. Quarterman, } 534 \text { F. 3d } \\
365 \text { (5th Cir. } 2008 \text { on remand to, } \\
\text { Hall v. Quarterman, } \\
2009 \text { WL } 612559 \text { (N.D. Tex. } \\
2009 \text { ), certificate of appealability } \\
\text { den. sub. nom., Hall v. Thaler } \\
597 \text { F.3d } 746 \text { (5th Cir. } 2010 \text { ), } \\
\text { cert. denied, } 562 \text { U.S. } 981 \\
\text { (2010). } \\
\text { For earlier litigation in the Hall } \\
\text { case, see, e.g., Hall v. } \\
\text { Quarterman, } 236 \text { F. App'x } 10 \\
\text { (5th Cir. 2007). }\end{array}$ & $\begin{array}{l}\text { Partial } \\
\text { Partial } \\
\text { turned } \\
\text { failure- } \\
\text { executed }\end{array}$ \\
\hline $\begin{array}{l}\text { Harris, Robert } \\
\text { Wayne }\end{array}$ & $\begin{array}{l}\text { Harris v. Thaler, } 464 \text { F. App'x } \\
301 \text { (5th Cir. 2012), cert den. } \\
\text { and stay den., } 567 \text { U.S. } 966 \\
(2012) \text {. }\end{array}$ & $\begin{array}{l}\text { No } \\
\text { Failure }\end{array}$ \\
\hline
\end{tabular}




\begin{tabular}{|c|c|c|}
\hline $\begin{array}{l}\text { Hearn, Yokamon } \\
\text { Laneal }\end{array}$ & $\begin{array}{l}\text { Hearn v. Thaler, } 669 \text { F. } 3 d 265 \\
\text { (5th Cir. 2012), cert den., } 576 \\
\text { U.S. } 954 \text { (2012). For earlier } \\
\text { litigation in the Hearn case, see, } \\
\text { e.g., } \\
\text { In re Hearn, } 418 \text { F. } 3 d 444 \text { (5th } \\
\text { Cir. } 2005 \text { ); Hearn v. Dretke (In } \\
\text { re Yokamon Laneal Hearn), } \\
376 \text { F. 3d } 447 \text { (5th Cir. } 2004 \text { ); } \\
\text { and Hearn v. Dretke, } 389 \text { F. 3d } \\
122 \text { (5th Cir. 2004). }\end{array}$ & $\begin{array}{l}\text { Partial } \\
\text { Partial } \\
\text { turned } \\
\text { failure- } \\
\text { executed }\end{array}$ \\
\hline $\begin{array}{l}\text { Henderson, } \\
\text { James Lee }\end{array}$ & $\begin{array}{l}\text { Henderson v. Davis, } 868 \text { F. 3d } \\
314 \text { (5th Cir. 2017). For earlier } \\
\text { litigation in the Henderson case, } \\
\text { see, e.g., Henderson v. } \\
\text { Stephens, } 791 \text { F. 3d } 567 \text { (5th } \\
\text { Cir. 2015); Henderson v. } \\
\text { Thaler, } 626 \text { F. 3d } 773 \text { (5th Cir. } \\
\text { 2010); and In re Henderson, } \\
462 \text { F.3d } 413 \text { (5th Cir. 2006). }\end{array}$ & $\begin{array}{l}\text { Yes (SCR) } \\
\text { Success- } \\
\text { life }\end{array}$ \\
\hline $\begin{array}{l}\text { Hernandez, } \\
\text { Ramiro }\end{array}$ & $\begin{array}{l}\text { Hernandez v. Stephens, } 537 \text { F. } \\
\text { App'x } 531 \text { (5th Cir. 2013), cert } \\
\text { den., } 572 \text { U.S. } 1036 \text { (2014). }\end{array}$ & $\begin{array}{l}\text { No } \\
\text { Failure }\end{array}$ \\
\hline $\begin{array}{l}\text { Hernandez, } \\
\text { Rodrigo }\end{array}$ & $\begin{array}{l}\text { Hernandez v. Thaler, } 398 \text { F. } \\
\text { App'x } 81 \text { (5th Cir. 2010), cert } \\
\text { den., } 563 \text { U.S. } 940(2011) \text {. }\end{array}$ & $\begin{array}{l}\text { No } \\
\text { Failure }\end{array}$ \\
\hline $\begin{array}{l}\text { Hines, Bobby } \\
\text { Lee }\end{array}$ & $\begin{array}{l}\text { Hines v. Thaler, } 456 \text { F. App'x } \\
357 \text { (5th Cir. 2011), cert den., } \\
566 \text { U.S. } 997 \text { (2012). For } \\
\text { subsequent litigation, see Ex } \\
\text { parte Hines, } 2012 \text { WL } 4928863 \\
\text { (Tex. Crim. App., Oct. } 15, \\
\text { 2012) (dismissing writ of } \\
\text { habeas corpus, and denying } \\
\text { stay of execution). }\end{array}$ & $\begin{array}{l}\text { No } \\
\text { Failure }\end{array}$ \\
\hline
\end{tabular}




\begin{tabular}{|c|c|c|}
\hline $\begin{array}{l}\text { Ibarra, Ramiro } \\
\text { Rubi }\end{array}$ & $\begin{array}{l}\text { Ibarra v. Davis, } 786 \text { F. App'x } \\
420 \text { (5th Cir. 2019), cert den., } \\
207 \text { L. Ed. 2d } 174 \text { (2020). For } \\
\text { earlier litigation in the Eldridge } \\
\text { case, see, e.g., Ibarra v. Davis, } \\
738 \text { F. App'x } 814 \text { (5th Cir. } \\
\text { 2018); Ibarra v. Stephens, } 723 \\
\text { F. 3d 599 (5th Cir. 2013); } \\
\text { Ibarra v. Thaler, } 687 \text { F. 3d } 222 \\
\text { (5th Cir. 2012); and Ibarra v. } \\
\text { Thaler, 691 F. 3d } 677 \text { (5th Cir. } \\
\text { 2012). }\end{array}$ & $\begin{array}{l}\text { No } \\
\text { Failure }\end{array}$ \\
\hline $\begin{array}{l}\text { Johnson, Derrick } \\
\text { Lamone }\end{array}$ & $\begin{array}{l}\text { In re Johnson, } 325 \text { F. App'x } 337 \\
\text { (5th Cir. 2009). }\end{array}$ & $\begin{array}{l}\text { No } \\
\text { Failure }\end{array}$ \\
\hline Johnson, Dexter & $\begin{array}{l}\text { Johnson v. Davis (In re } \\
\text { Johnson), } 935 \text { F. 3d } 284 \text { (5th } \\
\text { Cir. 2019), cert. denied, } 140 \mathrm{~S} . \\
\text { Ct. } 2521 \text { (2020). For earlier } \\
\text { litigation in the Johnson case, } \\
\text { see, e.g., Johnson v. Stephens, } \\
617 \text { F. App'x } 293 \text { (5th Cir. } \\
2015) \text {, cert denied, } 136 \text { S. Ct. } 980 \\
(2016) \text {. }\end{array}$ & $\begin{array}{l}\text { Yes } \\
\text { Maybe a } \\
\text { success }\end{array}$ \\
\hline $\begin{array}{l}\text { Johnson, Kia } \\
\text { Levoy }\end{array}$ & $\begin{array}{l}\text { In re Johnson, } 334 \text { F. } 3 d 403 \\
\text { (5th Cir. 2003). }\end{array}$ & $\begin{array}{l}\text { No } \\
\text { Failure }\end{array}$ \\
\hline $\begin{array}{l}\text { Ladd, Robert } \\
\text { Charles }\end{array}$ & $\begin{array}{l}\text { Ladd v. Livingston, } 777 \text { F. 3d } \\
286 \text { (5th Cir. 2015), cert. denied, } \\
574 \text { U.S. } 1144 \text { (2015). For } \\
\text { earlier litigation in the Ladd } \\
\text { case, see, e.g., Ladd v. } \\
\text { Stephens, } 748 \text { F. 3d } 637 \text { (5th } \\
\text { Cir. 2014), cert. denied, } 574 \text { U.S. } \\
880 \text { (2014). }\end{array}$ & $\begin{array}{l}\text { Partial } \\
\text { Partial } \\
\text { turned } \\
\text { failure- } \\
\text { executed }\end{array}$ \\
\hline Lewis, David Lee & $\begin{array}{l}\text { In re Lewis, } 484 \text { F. 3d } 793 \text { (5th } \\
\text { Cir. 2007), cert. denied, } 552 \text { U.S. } \\
1141 \text { (2008). }\end{array}$ & $\begin{array}{l}\text { No } \\
\text { Failure }\end{array}$ \\
\hline
\end{tabular}




\begin{tabular}{|c|c|c|}
\hline $\begin{array}{l}\text { Lewis, Rickey } \\
\text { Lynn }\end{array}$ & $\begin{array}{l}\text { Lewis v. Thaler, } 701 \text { F. 3d } 783 \\
\text { (5th Cir. 2012), cert. denied, } 569 \\
\text { U.S. } 910 \text { (2013). For earlier } \\
\text { litigation in the Lewis case, see, } \\
\text { e.g., } \\
\text { Lewis v. Quarterman, } 541 \text { F. 3d } \\
280 \text { (5th Cir. 2008) and Lewis } \\
\text { v. Quarterman, 272 F. App'x } \\
347 \text { (5th Cir. 2008). }\end{array}$ & $\begin{array}{l}\text { Partial } \\
\text { Partial } \\
\text { turned } \\
\text { failure- } \\
\text { executed }\end{array}$ \\
\hline $\begin{array}{l}\text { Long, Steven } \\
\text { Lynn }\end{array}$ & $\begin{array}{l}\text { Long v. Davis, } 706 \text { F. App'x } 181 \\
\text { (5th Cir. 2017), supplemented on } \\
\text { other grounds, sub.. nom., Long v. } \\
\text { Davis, } 138 \text { S. Ct. } 72 \text { (2017). For } \\
\text { earlier litigation in the Long } \\
\text { case, see, e.g., Long v. Davis, } \\
663 \text { F. App'x } 361 \text { (5th Cir. } \\
\text { 2016). }\end{array}$ & $\begin{array}{l}\text { Yes (SCR) } \\
\text { Maybe a } \\
\text { success }\end{array}$ \\
\hline $\begin{array}{l}\text { Maldonado, } \\
\text { Virgilio }\end{array}$ & $\begin{array}{l}\text { Maldondao v. Thaler, } 625 \text { F. } 3 d \\
229 \text { (5th Cir. } 2010) \text {, cert. denied, } \\
565 \text { U.S. } 829 \text { (2011). For earlier } \\
\text { litigation in the Maldonado } \\
\text { case, see, e.g., Maldonado v. } \\
\text { Thaler, } 5 \text { th Cir. } 2010 \text { U.S. App } \\
\text { LEXIS } 17735 \text { and Maldonado } \\
\text { v. Thaler, } 389 \text { F. App'x } 399 \\
\text { (5th Cir. } 2010) \text {, cert. denied, } 565 \\
\text { U.S. } 829(2011) \text {. . }\end{array}$ & $\begin{array}{l}\text { Partial } \\
\text { Partial } \\
\text { turned } \\
\text { failure } \\
\text { On death } \\
\text { row }\end{array}$ \\
\hline $\begin{array}{l}\text { Martinez, } \\
\text { Raymond Deleon }\end{array}$ & $\begin{array}{l}\text { Martinez v. Davis, } 653 \text { F. App'x } \\
308 \text { (5th Cir. 2016), } \\
\text { s upplemented on other grounds, } \\
\text { sub. nom., Martinez v. Davis, } 137 \\
\text { S. Ct. } 1432 \text { (2017). }\end{array}$ & $\begin{array}{l}\text { Yes (SCR) } \\
\text { Success } \\
\text { died in } \\
\text { prison }\end{array}$ \\
\hline $\begin{array}{l}\text { Matamoros, John } \\
\text { Reyes }\end{array}$ & $\begin{array}{l}\text { Matamoros v. Stephens, } 783 \mathrm{~F} . \\
\text { 3d } 212 \text { (5th Cir. } 2015 \text { ). For } \\
\text { earlier litigation in the } \\
\text { Matamoros case, see, e.g., } \\
\text { Matamoros v. Stephens, } 539 \text { F. } \\
\text { App'x } 487 \text { (5th Cir. 2013). }\end{array}$ & $\begin{array}{l}\text { Partial } \\
\text { Partial } \\
\text { turned } \\
\text { failure- } \\
\text { died in } \\
\text { prison }\end{array}$ \\
\hline
\end{tabular}




\begin{tabular}{|c|c|c|}
\hline $\begin{array}{l}\text { Mathis, Milton } \\
\text { Wuzael }\end{array}$ & $\begin{array}{l}\text { Mathis v. Thaler, } 616 \text { F. 3d } 461 \\
\text { (5th Cir. 2010), cert. denied, } 562 \\
\text { U.S. } 1257 \text { (2011). For earlier } \\
\text { litigation in the Mathis case, } \\
\text { see, e.g., } \\
\text { In re Mathis, } 483 \text { F. } 3 \text { d } 395 \text { (5th } \\
\text { Cir. } 2007 \text { ) and Mathis v. } \\
\text { Dretke, } 124 \text { F. App'x } 865 \text { (5th } \\
\text { Cir. } 2005) \text {, cert. denied, } 545 \text { U.S. } \\
1131 \text { (2005). }\end{array}$ & $\begin{array}{l}\text { Partial } \\
\text { Partial } \\
\text { turned } \\
\text { failure- } \\
\text { executed }\end{array}$ \\
\hline $\begin{array}{l}\text { Mays, Randall } \\
\text { Wayne }\end{array}$ & $\begin{array}{l}\text { Mays v. Stephens, } 757 \text { F. 3d } 211 \\
\text { (5th Cir. 2014), cert. denied, } 574 \\
\text { U.S. } 1082(2015) \text {. }\end{array}$ & $\begin{array}{l}\text { No } \\
\text { Failure }\end{array}$ \\
\hline Moore, Curtis & $\begin{array}{l}\text { Moore v. Quarterman, } 517 \text { F. } \\
\text { 3d } 781 \text { (5th Cir. 2008), cert. } \\
\text { denied, } 555 \text { U.S. } 842 \text { (2008). }\end{array}$ & $\begin{array}{l}\text { No } \\
\text { Failure }\end{array}$ \\
\hline $\begin{array}{l}\text { Moore, Eric } \\
\text { Lynn }\end{array}$ & $\begin{array}{l}\text { Moore v. Quarterman, 342 F. } \\
\text { App'x } 65 \text { (5th Cir. 2009), cert. } \\
\text { denied, } 559 \text { U.S. } 998 \text { (2010). For } \\
\text { earlier litigation in the Moore } \\
\text { case, see, e.g., Moore v. } \\
\text { Quarterman, 533 F. 3d } 338 \\
\text { (5th Cir. 2008); Moore v. } \\
\text { Quarterman, 520 F. 3d 504 } \\
\text { (5th Cir. 2008); Moore v. } \\
\text { Quarterman, 491 F. 3d } 213 \\
\text { (5th Cir. 2007); Moore v. } \\
\text { Quarterman, 454 F. 3d } 484 \\
\text { (5th Cir. 2006); Moore v. } \\
\text { Dretke, 369 F. 3d 844 (5th Cir. } \\
\text { 2004); and In re Moore, 67 F. } \\
\text { App'x 25 (5th Cir. 2003). }\end{array}$ & $\begin{array}{l}\text { Yes } \\
\text { Success- } \\
\text { life }\end{array}$ \\
\hline $\begin{array}{l}\text { Moreno, Jose } \\
\text { Angel }\end{array}$ & $\begin{array}{l}\text { Moreno v. Dretke, } 450 \text { F. } 3 \mathrm{~d} \\
158 \text { (5th Cir. } 2006) \text {, cert. denied, } \\
549 \text { U.S. } 1120(2007) .\end{array}$ & $\begin{array}{l}\text { No } \\
\text { Failure }\end{array}$ \\
\hline
\end{tabular}




\begin{tabular}{|c|c|c|}
\hline $\begin{array}{l}\text { Morris, Kenneth } \\
\text { Wayne }\end{array}$ & $\begin{array}{l}\text { Morris v. Quarterman, } 275 \text { F. } \\
\text { App'x } 292 \text { (5th Cir. 2008), cert. } \\
\text { denied, } 555 \text { U.S. } 904 \text { (2008), } \\
\text { s upplemented on other grounds, } \\
\text { sub. Nom., Morris v. Dretke, } 413 \\
\text { F. 3d } 484 \text { (5th Cir. 2005); } \\
\text { Morris v. Dretke, } 379 \text { F. 3d } 199 \\
\text { (5th Cir. 2004); and In re } \\
\text { Morris, } 328 \text { F. 3d } 739 \text { (5th Cir. } \\
\text { 2003). }\end{array}$ & $\begin{array}{l}\text { Yes } \\
\text { Partial } \\
\text { turned } \\
\text { failure- } \\
\text { executed }\end{array}$ \\
\hline $\begin{array}{l}\text { Nealy, Charles } \\
\text { Anthony }\end{array}$ & $\begin{array}{l}\text { In re Nealy, } 223 \text { F. App'x } 366 \\
\text { (5th Cir. 2007). }\end{array}$ & $\begin{array}{l}\text { No } \\
\text { Failure }\end{array}$ \\
\hline $\begin{array}{l}\text { Neville, Robert } \\
\text { James }\end{array}$ & $\begin{array}{l}\text { In re Neville, } 440 \text { F. 3d } 220 \text { (5th } \\
\text { Cir. 2006), supplemented on other } \\
\text { grounds, sub. Nom., Neville v. } \\
\text { Johnson, } 440 \text { F. 3d } 221 \text { ( } 2006) \text {, } \\
\text { cert. denied, } 546 \text { U.S. } 1161 \\
(2006) \text {. }\end{array}$ & $\begin{array}{l}\text { No } \\
\text { Failure }\end{array}$ \\
\hline $\begin{array}{l}\text { Perkins, } \\
\text { Reginald }\end{array}$ & $\begin{array}{l}\text { Perkins v. Quarterman, 254 F. } \\
\text { App'x } 366 \text { (5th Cir. 2007), cert. } \\
\text { denied, } 553 \text { U.S. } 1067 \text { (2008). }\end{array}$ & $\begin{array}{l}\text { No } \\
\text { Failure }\end{array}$ \\
\hline $\begin{array}{l}\text { Pierce, Anthony } \\
\text { L }\end{array}$ & $\begin{array}{l}\text { Pierce v. Thaler, 604 F. 3d } 197 \\
\text { (5th Cir. 2010). For earlier } \\
\text { litigation in the Moore case, see, } \\
\text { e.g., Pierce v. Thaler, } 355 \text { F. } \\
\text { App'x } 784 \text { (5th Cir. 2009). }\end{array}$ & $\begin{array}{l}\text { Yes } \\
\text { Success } \\
\text { Life }\end{array}$ \\
\hline $\begin{array}{l}\text { Ripkowski, Britt } \\
\text { Allen }\end{array}$ & $\begin{array}{l}\text { Ripkowski v. Thaler, } 438 \text { F. } \\
\text { App'x } 296 \text { (2011), cert. denied, } \\
565 \text { U.S. } 1205 \text { (2012). }\end{array}$ & $\begin{array}{l}\text { No } \\
\text { Failure }\end{array}$ \\
\hline $\begin{array}{l}\text { Rivera, Jose } \\
\text { Alfredo }\end{array}$ & $\begin{array}{l}\text { Rivera v. Quarterman, } 505 \text { F. } \\
\text { 3d } 349 \text { (5th Cir. } 2007) \text {, cert. } \\
\text { denied, } 555 \text { U.S. } 827 \text { (2008). }\end{array}$ & $\begin{array}{l}\text { Yes } \\
\text { Maybe a } \\
\text { success }\end{array}$ \\
\hline $\begin{array}{l}\text { Rockwell, Kwame } \\
\text { A }\end{array}$ & $\begin{array}{l}\text { Rockwell v. Davis, } 853 \text { F. 3d } 758 \\
\text { (5th Cir. 2017), cert. denied, } 138 \\
\text { S. Ct. } 215 \text { (2017). }\end{array}$ & $\begin{array}{l}\text { No } \\
\text { Failure }\end{array}$ \\
\hline Rosales, Michael & $\begin{array}{l}\text { Rosales v. Quarterman, } 565 \text { F. } \\
\text { 3d } 308 \text { (5th Cir. 2009), cert. } \\
\text { denied, } 556 \text { U.S. } 1176 \text { (2009). } \\
\text { For earlier litigation in the } \\
\text { Rosales case, see, e.g., Rosales v. } \\
\text { Quarterman, 291 F. App'x } 558 \\
\text { (5th Cir. 2008). }\end{array}$ & $\begin{array}{l}\text { Partial } \\
\text { turned } \\
\text { failure; } \\
\text { executed }\end{array}$ \\
\hline
\end{tabular}




\begin{tabular}{|c|c|c|}
\hline $\begin{array}{l}\text { Salazar, Robert } \\
\text { Madrid }\end{array}$ & $\begin{array}{l}\text { In re Salazar, } 443 \text { F. } 3 d 430 \text { (5th } \\
\text { Cir. 2006). For earlier litigation } \\
\text { in the Salazar case, see, e.g., } \\
\text { Salazar v. Dretke, } 419 \text { F. } 3 d \text { d } 384 \\
\text { (5th Cir. 2005), cert. denied, } 547 \\
\text { U.S. } 1006(2006) \text {. }\end{array}$ & $\begin{array}{l}\text { No } \\
\text { Failure }\end{array}$ \\
\hline $\begin{array}{l}\text { Segundo, Juan } \\
\text { Ramon Meza }\end{array}$ & $\begin{array}{l}\text { Segundo v. Davis, } 831 \text { F. 3d } 345 \\
\text { (5th Cir. 2016), cert. denied, } 137 \\
\text { S. Ct. } 1068 \text { (2017). }\end{array}$ & $\begin{array}{l}\text { No } \\
\text { Failure }\end{array}$ \\
\hline $\begin{array}{l}\text { Shisinday, } \\
\text { Shozdijiji }\end{array}$ & $\begin{array}{l}\text { Shisinday v. Quarterman, } 511 \\
\text { F. 3d } 514 \text { (5th Cir. } 2007) \text {, cert. } \\
\text { denied, } 555 \text { U.S. } 815 \text { (2008). }\end{array}$ & $\begin{array}{l}\text { No } \\
\text { Failure }\end{array}$ \\
\hline Shore, Anthony & $\begin{array}{l}\text { Shore v. Davis, } 845 \text { F. 3d } 627 \\
\text { (5th Cir. 2017), cert. denied, } 138 \\
\text { S. Ct. } 88 \text { (2017). }\end{array}$ & $\begin{array}{l}\text { No } \\
\text { Failure }\end{array}$ \\
\hline $\begin{array}{l}\text { Simpson, } \\
\text { Danielle }\end{array}$ & $\begin{array}{l}\text { Simpson v. Quarterman, 341 F. } \\
\text { App'x } 68 \text { (5th Cir. } 2009 \text { ), cert. } \\
\text { denied, } 558 \text { U.S. } 1039 \text { (2009). } \\
\text { For earlier litigation in the } \\
\text { Simpson case, see, e.g., Simpson } \\
\text { v. Quarterman, 291 F. App'x } \\
622 \text { (5th Cir. 2008). }\end{array}$ & $\begin{array}{l}\text { Partial } \\
\text { turned } \\
\text { failure; } \\
\text { executed }\end{array}$ \\
\hline Smith, Robert & $\begin{array}{l}\text { Smith v. Cockrell, } 311 \text { F. 3d } 661 \\
\text { (5th Cir. 2002), cert. granted in } \\
\text { part, } 539 \text { U.S. } 986(2003) \text {, cert. } \\
\text { dismissed, } 541 \text { U.S. } 913(2004) \text {. }\end{array}$ & $\begin{array}{l}\text { No } \\
\text { Failure }\end{array}$ \\
\hline $\begin{array}{l}\text { Soliz, Mark } \\
\text { Anthony }\end{array}$ & $\begin{array}{l}\text { In re Soliz, } 938 \text { F. 3d } 200 \text { (5th } \\
\text { Cir. 2019). For earlier litigation } \\
\text { in the Soliz case, see, e.g., } \\
\text { Soliz v. Davis, } 750 \text { F. App'x } 282 \\
\text { (5th Cir. } 2018) \text {, cert. denied, } 139 \\
\text { S. Ct. } 1447 \text { (2019). }\end{array}$ & $\begin{array}{l}\text { No } \\
\text { Failure }\end{array}$ \\
\hline $\begin{array}{l}\text { Sorto, Walter } \\
\text { Alexander }\end{array}$ & $\begin{array}{l}\text { Sorto v. Davis, } 716 \text { F. App'x } 366 \\
\text { (5th Cir. 2018). For earlier } \\
\text { litigation in the Sorto case, see, } \\
\text { e.g., Sorto v. Davis, } 881 \text { F. 3d } \\
933 \text { (5th Cir. 2018); Sorto v. } \\
\text { Davis, } 859 \text { F. 3d } 356 \text { (5th Cir. } \\
\text { 2017); and Sorto v. Davis, } 672 \\
\text { F. App'x } 342 \text { (5th Cir. 2016). }\end{array}$ & $\begin{array}{l}\text { Yes } \\
\text { Maybe a } \\
\text { success }\end{array}$ \\
\hline Sparks, Robert & $\begin{array}{l}\text { In re Sparks, } 939 \text { F. 3d } 630 \text { (5th } \\
\text { Cir. 2019). }\end{array}$ & $\begin{array}{l}\text { No } \\
\text { Failure } \\
\end{array}$ \\
\hline
\end{tabular}




\begin{tabular}{|c|c|c|}
\hline $\begin{array}{l}\text { Tamayo, Edgar } \\
\text { Arias }\end{array}$ & $\begin{array}{l}\text { Tamayo v. Stephens, } 740 \text { F. 3d } \\
991 \text { (5th Cir. 2014). For earlier } \\
\text { litigation in the Tamayo case, } \\
\text { see, e.g., Tamayo v. Perry, } 553 \\
\text { F. App'x } 395 \text { (5th Cir. 2014); In } \\
\text { re Tamayo, } 552 \text { F. App'x } 371 \\
\text { (5th Cir. 2014); Tamayo v. } \\
\text { Thaler, 5th Cir. } 2011 \text { U.S. App. } \\
\text { LEXIS 26665, and Tamayo v. } \\
\text { Thaler, 5th Cir. } 2011 \text { U.S. App. } \\
\text { LEXIS } 26671 .\end{array}$ & $\begin{array}{l}\text { No } \\
\text { Failure }\end{array}$ \\
\hline Taylor, Elkie Lee & $\begin{array}{l}\text { In re Taylor, } 298 \text { F. App'x } 385 \\
\text { (5th Cir. 2008). For earlier } \\
\text { litigation in the Taylor case, see, } \\
\text { e.g., Taylor v. Quarterman, } 498 \\
\text { F. 3d } 306 \text { (5th Cir. } 2007) \text {, cert. } \\
\text { denied, } 552 \text { U.S. } 1298 \text { (2008). }\end{array}$ & $\begin{array}{l}\text { No } \\
\text { Failure }\end{array}$ \\
\hline $\begin{array}{l}\text { Thomas, } \\
\text { Kenneth } \\
\text { Dewayne }\end{array}$ & $\begin{array}{l}\text { Thomas v. Quarterman, } 335 \mathrm{~F} \text {. } \\
\text { App'x } 386 \text { (5th Cir. 2009), cert. } \\
\text { denied, } 558 \text { U.S. } 1117(2010) \text {. } \\
\text { For earlier litigation in } \\
\text { the Thomas case, see, e.g., In re } \\
\text { Thomas, } 225 \text { F. App'x } 222 \text { (5th } \\
\text { Cir. 2007) and Thomas v. } \\
\text { Cockrell, } 54 \text { F. App'x } 591 \\
(2002) \text {, cert. denied, } 538 \text { U.S. } \\
965 \\
(2003) \text {. }\end{array}$ & $\begin{array}{l}\text { Yes } \\
\text { Success; } \\
\text { life or } \\
\text { possibly } \\
\text { less }\end{array}$ \\
\hline $\begin{array}{l}\text { Turner, Edwin } \\
\text { Hart }\end{array}$ & $\begin{array}{l}\text { Turner v. Epps, } 460 \text { F. App'x } \\
322 \text { (5th Cir. 2012). }\end{array}$ & $\begin{array}{l}\text { No } \\
\text { Failure }\end{array}$ \\
\hline $\begin{array}{l}\text { Ward, Adam } \\
\text { Kelly }\end{array}$ & $\begin{array}{l}\text { Ward v. Stephens, } 777 \text { F. 3d } \\
250 \text { (5th Cir. 2015), cert. denied, } \\
136 \text { S. Ct. } 86 \text { (2015). }\end{array}$ & $\begin{array}{l}\text { No } \\
\text { Failure }\end{array}$ \\
\hline $\begin{array}{l}\text { Weathers, Obie } \\
\text { D }\end{array}$ & $\begin{array}{l}\text { Weathers v. Davis, } 659 \text { F. App'x } \\
778 \text { (5th Cir. 2016), vacated and } \\
\text { remanded, Weathers v. Davis, } \\
138 \text { S. Ct. } 315,199 \text { L. Ed. 2d } \\
203 \text { (2017). }\end{array}$ & $\begin{array}{l}\text { Yes (SCR) } \\
\text { Maybe a } \\
\text { success }\end{array}$ \\
\hline
\end{tabular}




\begin{tabular}{|c|c|c|}
\hline $\begin{array}{l}\text { Webster, Bruce } \\
\text { Carneil }\end{array}$ & $\begin{array}{l}\text { In re Webster, } 605 \text { F. 3d } 256 \\
\text { (5th Cir. 2010), cert. denied, } 562 \\
\text { U.S. } 1091 \text { (2010). For earlier } \\
\text { litigation in the Webster case, } \\
\text { see, e.g., } \\
\text { United States v. Webster, } 421 \text { F. } \\
\text { 3d } 308 \text { (5th Cir. 2005), } \\
\text { rehearing en banc den., 174 F. } \\
\text { App'x } 863 \text { (5th Cir. 2006), cert. } \\
\text { denied, } 549 \text { U.S. } 828 \text { (2006) and } \\
\text { United States v. Webster, } 392 \text { F. } \\
\text { 3d } 787 \text { (5th Cir. 2004). }\end{array}$ & $\begin{array}{l}\text { No } \\
\text { Failure }\end{array}$ \\
\hline Wiley, William & $\begin{array}{l}\text { Wiley v. Epps, } 625 \text { F. 3d } 199 \\
\text { (5th Cir. 2010). }\end{array}$ & $\begin{array}{l}\text { Yes } \\
\text { Success, } \\
\text { but died } \\
\text { on death } \\
\text { row }\end{array}$ \\
\hline $\begin{array}{l}\text { Williams, Clifton } \\
\text { Lamar }\end{array}$ & $\begin{array}{l}\text { Williams v. Stephens, } 761 \text { F. 3d } \\
561 \text { (5th Cir. 2014), cert. denied, } \\
575 \text { U.S. } 952 \text { (2015). }\end{array}$ & $\begin{array}{l}\text { No } \\
\text { Failure }\end{array}$ \\
\hline $\begin{array}{l}\text { Williams, Jeffrey } \\
\text { Demond }\end{array}$ & $\begin{array}{l}\text { Williams v. Thaler, } 602 \text { F. 3d } \\
291 \text { (5th Cir. } 2010) \text {, cert. denied, } \\
131 \text { S. Ct. } 506 \text { (2010). For } \\
\text { earlier litigation in the Williams } \\
\text { case, see, e.g., Williams v. } \\
\text { Quarterman, } 293 \text { F. App'x } 298 \\
\text { (5th Cir. 2008). }\end{array}$ & $\begin{array}{l}\text { No } \\
\text { Failure }\end{array}$ \\
\hline $\begin{array}{l}\text { Wilson, Marvin } \\
\text { Lee }\end{array}$ & $\begin{array}{l}\text { Wilson v. Thaler, } 450 \text { F. App'x } \\
369 \text { (5th Cir. 2011), cert. denied } \\
\text { and stay den., } 567 \text { U.S. } 958 \\
\text { (2012). For earlier litigation in } \\
\text { the Wilson case, see, e.g., In re } \\
\text { Wilson, } 442 \text { F. 3d } 872 \text { (5th Cir. } \\
\text { 2006) and In re Wilson, } 433 \text { F. } \\
\text { 3d 451 (5th Cir. 2005). }\end{array}$ & $\begin{array}{l}\text { Partial } \\
\text { Turned } \\
\text { failure; } \\
\text { executed }\end{array}$ \\
\hline $\begin{array}{l}\text { Wood, David } \\
\text { Leonard }\end{array}$ & $\begin{array}{l}\text { In re Wood, } 648 \text { F. App'x } 388 \\
\text { (5th Cir. 2016). }\end{array}$ & $\begin{array}{l}\text { No } \\
\text { Failure }\end{array}$ \\
\hline $\begin{array}{l}\text { Woods, Bobby } \\
\text { Wayne }\end{array}$ & $\begin{array}{l}\text { Woods v. Quarterman, } 493 \text { F. 3d } \\
580 \text { (5th Cir. 2007). For earlier } \\
\text { litigation in the Woods case, see, } \\
\text { e.g., In re Woods, } 155 \text { F. App'x } \\
132 \text { (5th Cir. 2005). }\end{array}$ & $\begin{array}{l}\text { Partial } \\
\text { turned } \\
\text { failure; } \\
\text { executed }\end{array}$ \\
\hline
\end{tabular}




\section{APPENDIX C}

Butler: Texas Court of Criminal Appeals remanded to habeas court "to consider evidence in light of the Moore I and II opinions and to make a recommendation to this Court on the issue of intellectual disability." 311 According to counsel, the district attorney is seeking to bring in a new expert in to test Butler and has said that if his full-scale IQ is 75 or below, he will settle. ${ }^{312}$

Campbell: Case was ultimately resolved in federal court without an evidentiary hearing. The Attorney General hired an expert to review the extensive documentary evidence concerning Campbell's background, and he apparently advised them that the defendant was likely to prevail on his Atkins claim, so a stipulated order was agreed to, finding that the defendant had an intellectual disability. ${ }^{313}$ Campbell was subsequently re-sentenced to life in prison with the possibility of parole. ${ }^{314}$ His counsel believes the likelihood that Robert will ever be released on parole is "very small." 315

\section{Cathey: No response from counsel.}

\section{Chase: No response from counsel.}

Johnson: After the Fifth Circuit entered a stay of execution and authorized the successor petition, Johnson's case was remanded to the district court. His counsel filed a new habeas petition

311. Ex parte Butler, No. WR-41,121-03, slip op. at *4 (Tex. Crim. App. Sept. 18, 2019) (per curiam) (on Application for Writ of Habeas Corpus, Cause No. 511112 in the 185th District Court, Harris County) (on file with authors).

312. E-mail from Richard Burr, appellate counsel for Butler, to the authors (June 8, 2020) (on file with authors).

313. See Joint Advisory Concerning Campbell's Intellectual Disability Claim at *7, Campbell v. Davis, No. 4:00-cy-03844 (S.D. Tex. May 10, 2017) (on file with authors).

314. He was reviewed in early 2018 for possible release on parole. Parole was officially denied on March 2, 2018 and he was given a seven-year "set-off," meaning that his next parole review was scheduled for February 2025. See Parole Review Information, TEX. DEP'T OF CRIMINAL JUSTICE, https://offender.tdcj.texas.gov/OffenderSearch/reviewDetail.action?sid=04286378\&tdcj=02141630\&fullName=CAMPBELL\%2CROBERT+JAMES (last visited Dec. 29, 2020).

315. E-mail from Robert Owen, appellate counsel for Campbell, to the authors (June 8,2020 ) (on file with authors). 
raising the Atkins claim, asking for a new hearing, and arguing that the defendant's intellectual disability is relevant to tolling (on the question of his diligence in pursuing his rights). ${ }^{316}$ His lawyer believes the "odds are pretty good" that such a hearing will be scheduled. ${ }^{317}$

Long: Defendant has recently had a state habeas evidentiary hearing; there has been no decision as of yet. ${ }^{318}$

Moore: Appellate counsel has had no contact with defendant since sentence commuted. ${ }^{319}$

Pierce: Currently serving life sentence. ${ }^{320}$

Rivera: The district court agreed to abate the case so that counsel could seek a commutation of the defendant's sentence. Counsel filed a request with the Texas Board of Pardons and Paroles, and that board unanimously agreed that defendant's sentence should be commuted to life without parole based on his intellectual disability. Counsel asked Governor Rick Perry to commute his sentence (as part of the commutation process in Texas, the Governor must agree to commutation). Over a six-year period, this was never acted upon by then-Governor Perry. Although the trial judge administratively abated the case in 2014 , since Governor Abbott took office in 2015, the defendant has remained on death row (but without an execution date) since 2003.

The district judge issued an Order on May 11, 2020 asking whether to go forward with a hearing on equitable tolling. Counsel then (1) sent a letter to Governor Abbott on May 23, 2020, asking to have Mr. Rivera's sentence commuted to life without parole, and

316. See Amended Second or Successive Petition for Writ of Habeas Corpus at *1, *31, *51-52, Johnson v. Davis, No. 4:19-CV-03047 (S.D. Tex. Nov. 12, 2019) (on file with authors).

317. E-mail from Jessica Graf, appellate counsel for Johnson, to the authors (June 8, 2020) (on file with authors); E-mail from Jeremy Schepers, appellate counsel for Johnson, to the authors (July 15, 2020) (on file with authors).

318. E-mail from Scott Smith, appellate counsel for Moore, to the authors (June 8, 2020) (on file with authors) (noting that Long's last four IQ tests were scored at 62, 63, 64, and 63, an "amazing consistency").

319. Id.; see also Moore v. Dretke, No. Civ.A. 603CV224, 2005 WL 1606437, at*12 (E.D. Tex. 2005).

320. E-mail from David Dow, appellate counsel for Pierce, to the authors (June 8, 2020) (on file with authors). 
(2) filed a Joint Advisory with the district court, informing the court of these proceedings, and asking the court to give the Governor time to act.

In light of the decision of the Texas Court of Criminal appeals in Ex Parte Moore, 587 S.W.3d 787 (Tex. Ct. Crim. App. 2019), counsel remains "hopeful" that Governor Abbott will commute Rivera's sentence. ${ }^{321}$

Sorto: Counsel has obtained funding to do additional texting on question of intellectual disability. ${ }^{322}$

Thomas: No response from counsel.

Weathers: Counsel is working on a state successor petition, following remand from Supreme Court on basis of Moore case. ${ }^{323}$

321. E-mail from Cathy Smith, appellate counsel for Rivera, to the authors (June 8, 2020) (on file with authors).

322. E-mail from David Dow, appellate counsel for Pierce, to the authors (June 8, 2020) (on file with authors).

323. E-mail from John "Bud" Ritenour, current counsel for Weathers, to the authors (July 13, 2020) (on file with authors). 
